\title{
Fluid and source magma evolution of the Questa porphyry Mo deposit, New Mexico, USA
}

\section{Journal Article}

Author(s):

Klemm, Leonhard M.; Pettke, Thomas; Heinrich, Christoph A. (D)

Publication date:

2008-07

Permanent link:

https://doi.org/10.3929/ethz-b-000014504

Rights / license:

In Copyright - Non-Commercial Use Permitted

Originally published in:

Mineralium Deposita 43(5), https://doi.org/10.1007/s00126-008-0181-7 


\title{
Fluid and source magma evolution of the Questa porphyry Mo deposit, New Mexico, USA
}

\author{
Leonhard M. Klemm • Thomas Pettke • \\ Christoph A. Heinrich
}

Received: 5 July 2006 / Accepted: 3 March 2008 / Published online: 20 May 2008

(C) Springer-Verlag 2008

\begin{abstract}
Combined fluid inclusion microthermometry and microanalysis by laser ablation inductively coupled plasma mass spectrometry (LA-ICPMS) are used to constrain the hydrothermal processes forming a typical Climax-type porphyry Mo deposit. Molybdenum mineralisation at Questa occurred in two superimposed hydrothermal stages, a magmatic-hydrothermal breccia and later stockwork veining. In both stages, texturally earliest fluids were single-phase, of low salinity $\left(\sim 7 \mathrm{wt} . \% \mathrm{NaCl}_{\text {equiv. }}\right)$ and intermediate-density. Upon decompression to $\sim 300$ bar, they boiled off a vapour phase, leaving behind a residual brine (up to 45 wt. $\% \mathrm{NaCl}_{\text {equiv }}$ ) at temperatures of $\sim 420^{\circ} \mathrm{C}$. The highest average Mo concentrations in this hot brine were $\sim 500 \mu \mathrm{g} / \mathrm{g}$, exceeding the Mo content of the intermediate-density input fluid by about an order of magnitude and reflecting pre-concentration of Mo by fluid phase separation prior to $\mathrm{MoS}_{2}$ deposition from the brine. Molybdenum concentrations in brine inclusions, then,
\end{abstract}

Editorial handling: B. Lehmann

Electronic supplementary material The online version of this article (doi:10.1007/s00126-008-0181-7) contains supplementary material, which is available to authorized users.

L. M. Klemm • T. Pettke · C. A. Heinrich $(\bowtie)$

Isotope Geochemistry and Mineral Resources,

Department of Earth Sciences,

Eidgenössische Technische Hochschule Zurich,

Clausiusstrasse 25,

8092 Zurich, Switzerland

e-mail: heinrich@erdw.ethz.ch

T. Pettke

Institute of Geological Sciences, University of Bern,

Baltzerstrasse $1+3$,

3012 Bern, Switzerland decrease down to $5 \mu \mathrm{g} / \mathrm{g}$, recording Mo precipitation in response to cooling of the saline liquid to $\sim 360^{\circ} \mathrm{C}$. Molybdenite precipitation from a dense, residual and probably sulphide-depleted brine is proposed to explain the tabular shape of the ore body and the absence of $\mathrm{Cu}$ $\mathrm{Fe}$ sulphides in contrast to the more common $\mathrm{Cu}-\mathrm{Mo}$ deposits related to porphyry stocks. Cesium and $\mathrm{Rb}$ concentrations in the single-phase fluids of the breccia range from 2 to 8 and from 40 to $65 \mu \mathrm{g} / \mathrm{g}$, respectively. In the stockwork veins, $\mathrm{Cs}$ and $\mathrm{Rb}$ concentrations are significantly higher (45-90 and 110-230 $\mu \mathrm{g} / \mathrm{g}$, respectively). Because $\mathrm{Cs}$ and $\mathrm{Rb}$ are incompatible and hydrothermally non-reactive elements, the systematic increase in their concentration requires two distinct pulses of fluid exsolution from a progressively more fractionated magma. By contrast, major element and ore metal concentrations of these two fluid pulses remain essentially constant. Mass balance calculations using fluid chemical data from LAICPMS suggest that at least $25 \mathrm{~km}^{3}$ of melt and $7 \mathrm{Gt}$ of deep input fluid were necessary to provide the amount of Mo contained in the stockwork vein stage alone. While the absolute amounts of fluid and melt are uncertain, the wellconstrained element ratios in the fluids together with empirical fluid/melt partition coefficients derived from the inclusion analyses suggest a high water content of the source melt of $\sim 10 \%$. In line with other circumstantial evidence, these results suggest that initial fluid exsolution may have occurred at a confining pressure exceeding 5 kbar. The source of the molybdenum-mineralising fluids probably was a particularly large magma chamber that crystallised and fractionated in the lower crust or at midcrustal level, well below the shallow intrusions immediately underlying Questa and other porphyry molybdenum deposits. 
Keywords Porphyry molybdenum · Fluid inclusion · Questa

\section{Introduction}

The global molybdenum supply is almost completely mined from porphyry-type ore deposits. Climax-type porphyry Mo deposits are the most important sources and reserves, after Mo obtained as a valuable by-product of porphyry-Cu(-Mo-Au) deposits. Major Climax-type deposits contain amounts of Mo comparable to those of giant porphyry-CuMo deposits such as Chuquicamata, El Teniente and Bingham but at much higher grades (e.g. Singer et al. 2005; Carten et al. 1993). They represent an end member of porphyry style mineralisation characterised by high abundances of $\mathrm{Mo}$ and $\mathrm{F}$, but virtually no $\mathrm{Cu}$ and $\mathrm{Au}$. The deposits are associated with shallow intrusions of highsilica rhyolites and granites (Carten et al. 1993) and occur mainly along the North American Cordillera. Major deposits of this type are Climax, Colorado (Wallace et al. 1978), Urad-Henderson, Colorado (Carten et al. 1988) and Questa, New Mexico (Ishihara 1967), all three being located in a single major province in the Southwestern USA (Carten et al. 1993). Lead isotopes (Stein and Hannah 1985) revealed a lower-crustal origin (partial melting of biotite-bearing felsic granulite) of the magmas from which the Climax-type deposits in the Southwestern USA formed.

The chemical composition and the evolution of the magmatic-hydrothermal fluids are key to understanding the origin of metals and precipitation mechanisms in this type of deposit and also in Mo-depositing stages of ordinary $\mathrm{Cu}-\mathrm{Mo}$ porphyries. The aim of this study is to investigate the compositional evolution of the ore-forming fluid in a Climax-type Mo system and to evaluate the composition of the magmatic source versus the influence of precipitation and wall rock reaction mechanisms on the metal budget of the deposit. The Questa deposit, presently mined by Molycorp Inc., provides an excellent example of a major Climax-type deposit. Its petrography and mineralogy are comparatively simple, and much of the sample material contains free-grown quartz crystals ideal for fluid inclusion studies. Standard microscopic and microthermometric procedures combined with laser ablation inductively coupled plasma mass spectrometry (LAICPMS) were used to determine the physico-chemical properties of the ore-forming fluids and to investigate ore-forming processes.

The geology and petrography of the Questa Mo deposit and its surroundings has been studied e.g. by Ishihara (1967), Laughlin et al. (1969), Lipman et al. (1986), Johnson and Lipman (1988), Johnson et al. (1989), Johnson et al. (1990) and Czamanske et al. (1990). Most recently,
Ross et al. (2002) described the textural, petrographic and mineralogical zonation of the magmatic-hydrothermal breccia (MHBX), which hosts the main ore bodies. Earlier fluid inclusion studies led to the recognition of essentially three different types of high-temperature fluid inclusions: liquid-rich, high-salinity inclusions (brine: type $\mathrm{C}$ and $\mathrm{D}$ of Bloom 1981 and type III of Cline and Bodnar 1994), vapourrich, low-salinity inclusions (vapour: type B of Bloom 1981 and type II of Cline and Bodnar 1994) and liquid-rich, lowto-moderate-salinity inclusions (intermediate-density: type A and E of Bloom, 1981 and type I of Cline and Bodnar 1994). The brine was interpreted as having exsolved directly from the magma, based on an apparent lack of coeval vapour (Cline and Bodnar 1994). A recent fluid inclusion study by Rowe (2005) identified fluid phase separation in the system and interpreted brine inclusions homogenising by halite dissolution to be an effect of accidental entrapment of halite. Magma mixing has been suggested to be an important factor for the generation of metal-rich fluids at Questa (Jones 2002), but it remains unclear whether a selectively Mo-enriched precursor magma is ultimately required for Mo ore formation. Oxygen and hydrogen isotopes and gas analyses (Ar-He- $\left.\mathrm{N}_{2}\right)$ demonstrate that the ore-forming fluids at Questa are of magmatic origin with negligible meteoric component and that all facies of the breccia and the stockwork veins are chemically and isotopically identical (Ross et al. 2002, Rowe et al. 2003). Analysis of co-existing fluid and melt inclusions from miarolitic cavities of two barren intrusions within the Questa caldera has provided fluid-melt partition coefficients for a number of elements, linked to the degree of crystallisation of the magma at the time of local fluid exsolution (Audétat and Pettke 2003).

\section{Geologic setting}

The formation of the Questa porphyry Mo deposit is closely associated with the volcanic and tectonic activity during the Tertiary Rio Grande rifting at the Southeastern end of the Rocky mountain chain (Fig. 1a). Volcanism and magmatism during that time also formed the large San Juan volcanic field, as well as other Climax-type porphyry Mo deposits in the "Colorado mineral belt", including the two largest known in the world (Climax; Urad and Henderson). The Questa porphyry Mo deposit is one of the world's largest Mo-only porphyries, although many porphyry-CuMo deposits contain larger quantities of Mo as a byproduct. Questa is hosted in the Late Oligocene Questa Caldera (Fig. 1b), which is located within the Latir volcanic field. Volcanic activity in the Latir field started around 28 Ma ago and comprised the formation of stratovolcanoes, 

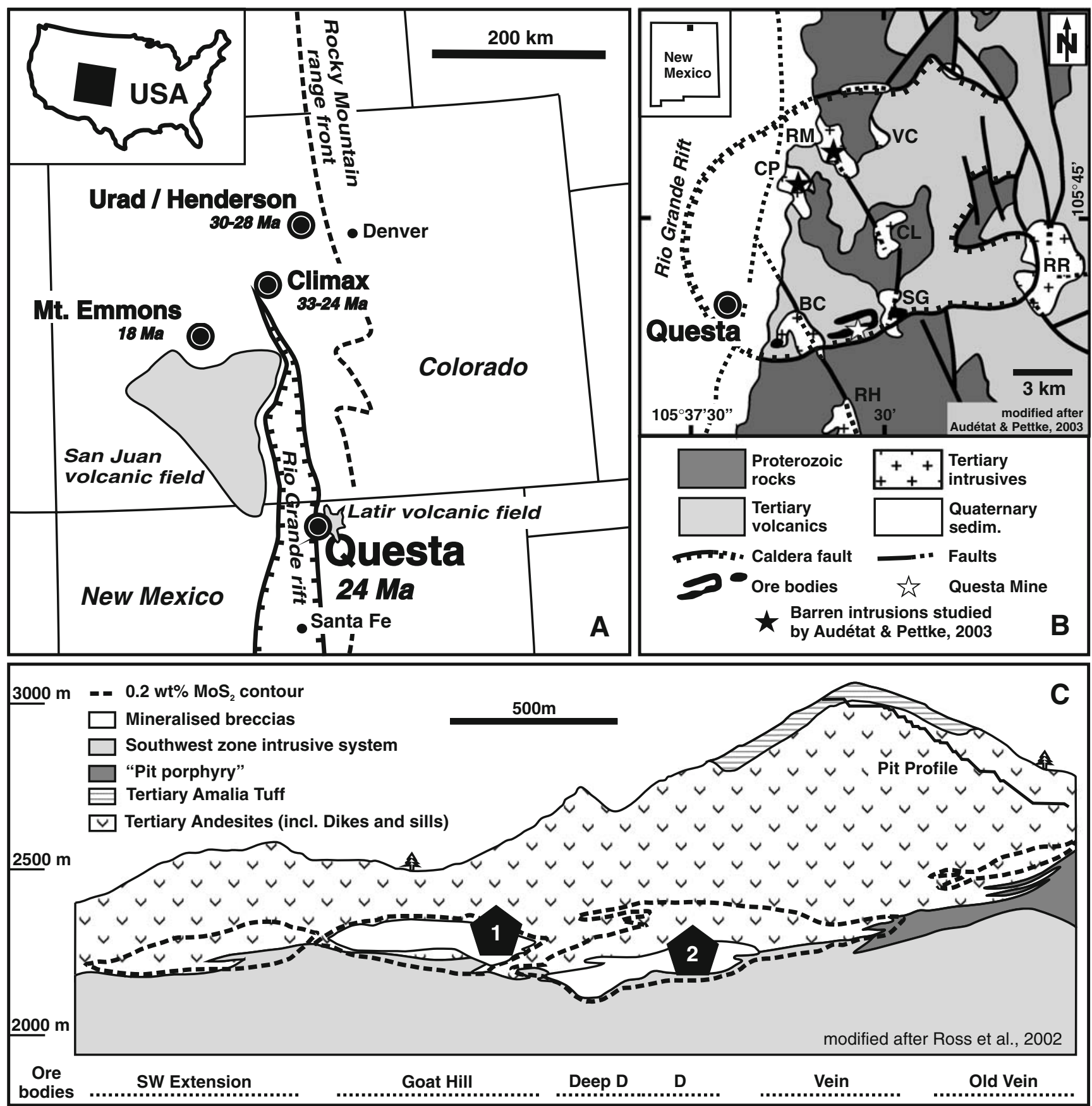

Fig. 1 a Regional tectonic map of Colorado and Northern New Mexico, location of a unique accumulation of Climax-type porphyry Mo deposits. b Geologic map of the Questa caldera after Lipman and Reed (1989). The Questa mine is located close to the southern caldera margin. Abbreviations used for post-caldera intrusions: $B C$-Bear Canyon, $S G$-Sulfur Gulch, $C L-$ Cabresto Lake, $C P$ - Cañada
Pinabete, $R M$ - Rito del Medio, $V C$-Virgin Canyon, $R R$ - Red River, $R H$ - Rio Hondo. c Schematic W-E vertical section through the southern limb of the horse-shoe-shaped array of tabular ore bodies, after Ross et al. (2002). The samples used for this study originate from drill core at locality 1 and from underground workings at locality 2

Pinabete, Rito del Medio, Virgin Cañon, Cabresto Lake) formed in the north and centre of the caldera within $1 \mathrm{Ma}$ after caldera formation. At the southern caldera margin, a number of intrusions (Sulfur Gulch, Red River and Bear Cañon) formed from $24.6 \pm 0.1$ to $24.1 \pm 0.2 \mathrm{Ma}$. The last magmatic activity in the region took place to the south lava domes and flows and volcanoclastic rocks of predominantly andesitic composition (e.g., Bethke and Lipman 1989, Johnson et al. 1989). The Caldera formed at $25.7 \pm$ $0.1 \mathrm{Ma}$ with the ejection of $>500 \mathrm{~km}^{3}$ of pyroclastic rocks, today preserved as the Amalia tuff (Czamanske et al. 1990). Granitic to rhyolitic post-caldera intrusions (Cañada 
outside the caldera margin, manifested by the Rio Hondo $(22.8 \pm 0.2 \mathrm{Ma})$ and Luzero Peak $(18.5 \pm 0.1 \mathrm{Ma})$ intrusions (Czamanske et al. 1990). Notable is the north to south "younging" of the intrusion ages. Molybdenum mineralisation is restricted to the southern intrusive stocks (Sulfur Gulch, Goat Hill, Bear Cañon, Red River, Lucero Peak and Rio Hondo). The Questa porphyry Mo deposit is mainly hosted in MHBX bodies and consists of several distinct ore bodies situated around and to the west of the Sulfur Gulch stock (Fig. 1c). The MHBX was dated to $24.2 \pm 0.3$ and $24.1 \pm 0.2 \mathrm{Ma}$ (Czamanske et al. 1990). The breccia bodies are hosted by fine-grained hornblende andesite with a porphyritic texture (Ishihara 1967) at the hanging wall intrusive contact of a pluton known as the southwest zone intrusive system (Fig. 1).

The current Mo mine is located in the "southwest zone" of the horseshoe-shaped mineralised body. The "Goat Hill" and "D" ore bodies (Fig. 1c) consist of a vertically zoned, clast-supported MHBX. Ross et al (2002) differentiated a vertical succession of seven breccia zones based on breccia matrix composition, clast petrography and alteration (zones A to E; Fig. 2). The lowest part of the MHBX consists of an igneous breccia with aplite matrix; clasts are angular, pervasively biotite-altered andesite and occasionally grey rhyolite porphyry (zone A1). The igneous breccia matrix grades upward into zones with hydrothermal breccia matrix

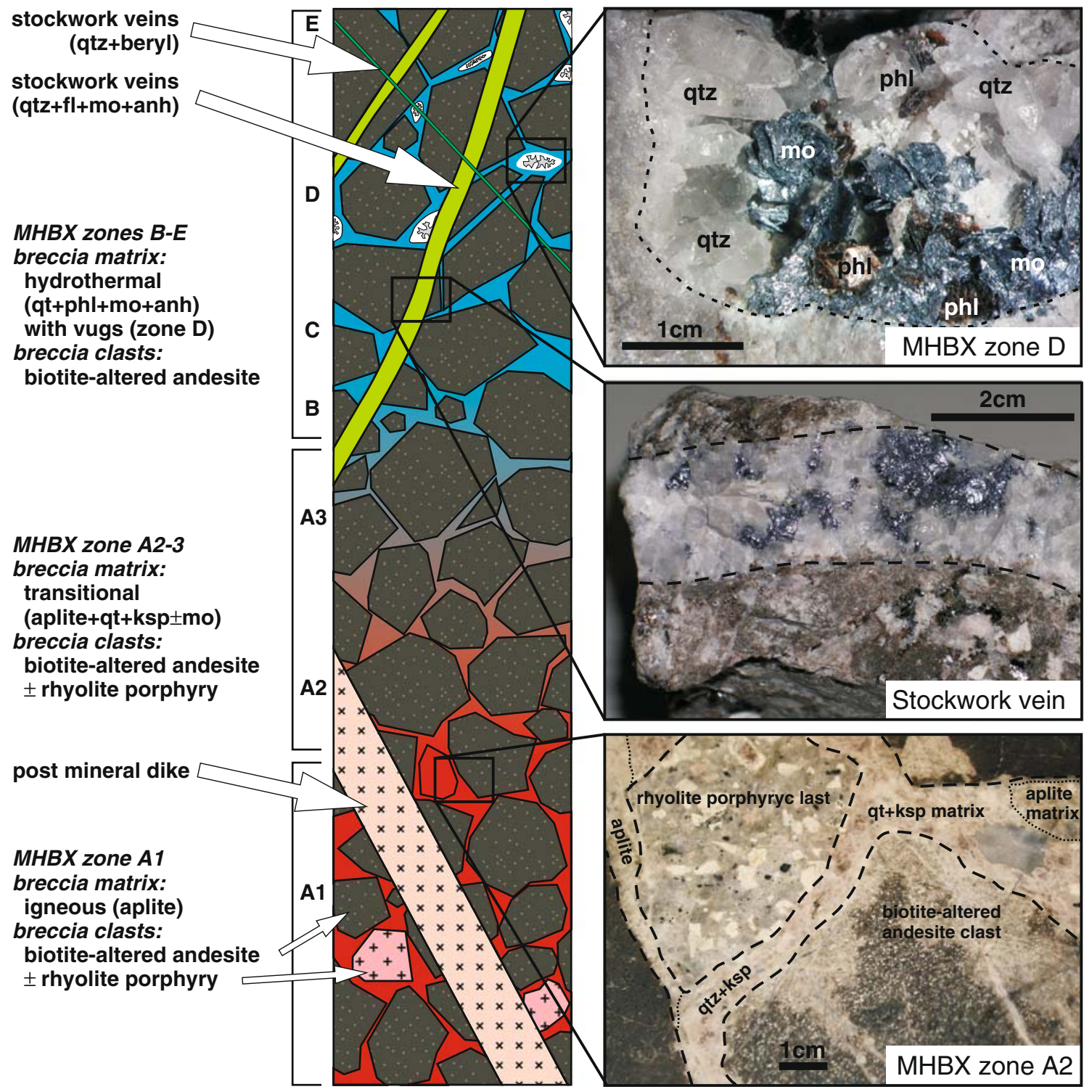

Fig. 2 Schematic vertical section through the Goat Hill and D ore bodies showing the gradually change from pure igneous to pure hydrothermal breccia matrix in the $M H B X$. Ross et al. (2002) distinguished seven facies within the MHBX (zones $A 1, A 2, A 3, B$, $C, D, E$ ) based on breccia matrix composition (mineralogy) and on rock type, alteration and shape of the clasts. Later features, such as stockwork veins and dikes, cut the breccia. This reconstruction is based on observations made in samples taken from core (DDH-2214), from underground workings and from the D ore body stockpile combined with the facies classification by Ross et al. (2002) 
(zones A2-A3). This transitional zone is characterised by segregations of quartz and orthoclase with minor amounts of molybdenite within an aplitic matrix. The upper part of the breccia contains a hydrothermal matrix consisting mainly of quartz, phlogopite and molybdenite (zones B, $\mathrm{C}, \mathrm{D}$ and E). Abundant vugs in zone D contain crystals of quartz and phlogopite, overgrown by molybdenite, which is overgrown by anhydrite, apatite and calcite. Remaining open space was probably filled with anhydrite (now dissolved) at the time when later stockwork and post-ore beryl veins cut the vuggy breccia (see below), as indicated by veins cutting across open vugs. The generally biotitealtered andesite clasts are angular in the lower parts and more rounded in the upper parts of the MHBX. The potassic alteration is overprinted by quartz-sericite alteration in the uppermost parts of the MHBX (zone E). Kilometre-scale propylitic alteration surrounds the ore deposit and is characterised by replacement of mafic minerals including hornblende, orthopyroxene and biotite with chlorite and epidote. More details on the classification of the different MHBX facies can be found in Ross et al. (2002).

Stockwork veins (quartz-fluorite-molybdenite-anhydrite) cut the MHBX. Molybdenite is intergrown with quartz; remaining open space was filled with fluorite and anhydrite. The veins studied here originate from the " $\mathrm{D}$ " ore body; they are up to $2 \mathrm{~cm}$ wide, straight-walled and have no visible alteration halo (Fig. 2).

Post-ore quartz-beryl \pm base metal sulphide veins, usually about $1 \mathrm{~cm}$ wide, cut across both the MHBX and the stockwork veins. Accessory minerals in these veins are chalcopyrite, fluorite, scheelite and sulphides or sulphosalts. The beryl crystals are up to $20 \mathrm{~mm}$ long and $1 \mathrm{~mm}$ in diameter. They are light-blue or emerald-green in colour.

Samples used for this study come from drill core (DDH$22-14^{\circ}$ ) through the Goat Hill ore body and from the D ore body stockpile. Additional samples from the stockpile are not well located but were selected to be petrographically unambiguous examples of the zone "D" after Ross et al. (2002) with a vuggy, hydrothermal breccia matrix.

Ross et al. (2002) estimated the contributions of the MHBX and the stockwork veins to the overall ore grades of the mine to be about $30 \%$ to $40 \%$ and $60 \%$ to $70 \%$, respectively. The late beryl vein stage is barren with respect to Mo.

\section{Methods}

Detailed petrography formed the basis for the selection of fluid inclusion assemblages (i.e. coevally trapped fluid inclusions in one geometrical feature). These were investigated with conventional microthermometry, scanning elec- tron microscope-cathodoluminscence (SEM-CL) imaging and LA-ICPMS microanalysis.

Microthermometry Phase transitions in fluid inclusions were determined using a Linkam TS600 heating-freezing stage. Calibration of the system was performed on synthetic fluid inclusion standards (SynFlinc ${ }^{\circledR}$ ), and temperature readings are considered to be accurate to within \pm 0.5 at $-60^{\circ} \mathrm{C}$, to within \pm 0.2 between $0^{\circ} \mathrm{C}$ and $100^{\circ} \mathrm{C}$, and to within $\pm 1^{\circ} \mathrm{C}$ above $100^{\circ} \mathrm{C}$. Salinities ( $\mathrm{NaCl}$ equivalent) were derived from final melting temperatures of $\mathrm{CO}_{2}-$ clathrate after Diamond (1992), from final melting of ice or from final melting temperatures of halite after Bodnar and Vityk (1994).

SEM-CL SEM-CL for imaging growth zones in quartz was performed using a CamScan CS44LB instrument at the Electron Microscopy Center of ETH Zürich. After carbon coating of the samples, backscattered electron and SEM-CL images of the same areas were acquired under identical analytical conditions (acceleration voltage of $15 \mathrm{kV}$, beamcurrent density of 9-13 nA/mm) using an EDAX Phoenix digital image acquisition system.

LA-ICPMS Selected inclusions were analysed individually with LA-ICPMS, using the instrumental setup described in Günther et al. (1998) and Heinrich et al. (2003) and analytical conditions similar to those reported in Pettke et al. (2004). A $193 \mathrm{~nm}$ ArF Excimer laser (Lambda Physik, Germany) combined with special beam energy homogenisation optics (Microlas, Germany) is linked with an Elan 6100 quadrupole ICPMS instrument (Perkin Elmer, Canada). For controlled ablation of the quartzhosted fluid inclusions, an energy density above $15 \mathrm{~J} / \mathrm{cm}^{2}$ on the sample and a laser pulse frequency of $10 \mathrm{~Hz}$ was used. The optical imaging system permits rapid switching between different pit sizes (4-120 $\mu \mathrm{m})$ at constant energy density on the sample by adjusting an aperture in the laser beam path. The ablation process was monitored both on the sample and as real-time signal on a monitor to ensure best possible control of the ablation process. For external standardisation, the National Institute of Standards and Technology reference material SRM-610 was used, yielding element concentration ratios for each inclusion. The concentration of $\mathrm{Na}$ in the fluid was, used as an internal standard to transform the element ratios into absolute concentrations. $\mathrm{Na}$ concentrations were derived from the microthermometric $\mathrm{NaCl}$ equivalent values, corrected for contributions of $\mathrm{KCl}, \mathrm{FeCl}_{2}, \mathrm{MnCl}_{2}, \mathrm{CuCl}$ and $\mathrm{PbCl}_{2}$ (Heinrich et al. 2003). Limits of detection (LOD) were calculated for each element in each inclusion, using the three standard deviation criteria (Longerich et al. 1996), except where stated otherwise. Results are plotted as single 
inclusion points in most of the subsequent diagrams, but averages and one standard deviation uncertainties of inclusion assemblages are discussed in the text.

\section{Results}

Fluid inclusion petrography and microthermometry

Fluid inclusions in quartz from the three stages of mineralisation, the MHBX, the stockwork veins and the
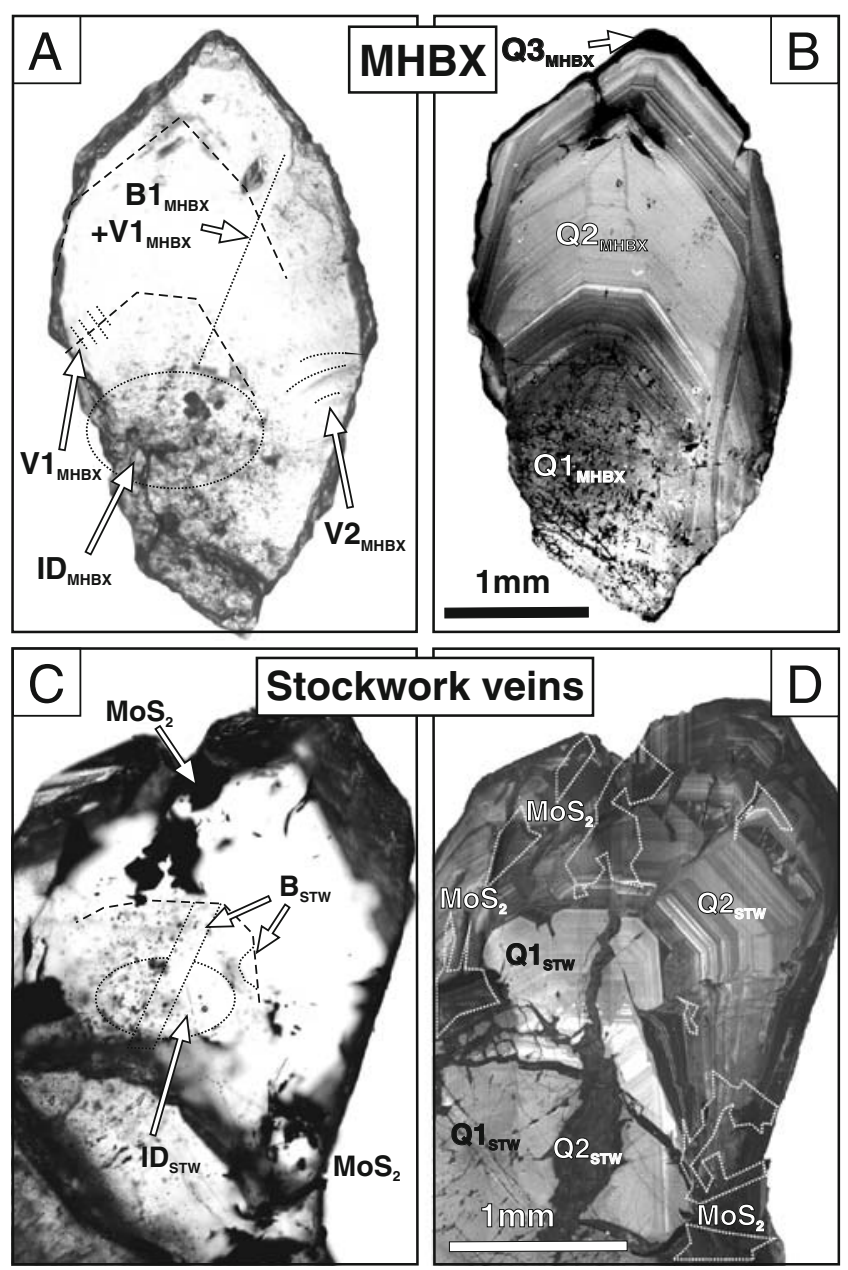

Fig. 3 a Photomicrograph in transmitted light of a polished section of a free-grown quartz crystal from the hydrothermal matrix of the magmatichydrothermal breccia $(M H B X)$. Note the distribution of fluid inclusions across the crystal. Growth zones are lined with phlogopite inclusions (highlighted with dashed lines). b Cathodoluminescence image of crystal shown in (a), revealing three different generations of quartz. Note the spotted pattern in the high fluid inclusion density area in $Q 1$. c Photomicrograph in transmitted light of a polished section of a freegrown quartz crystal from the stockwork vein stage (STW). Dashed lines show growth structures and fluid inclusion type age relationships. d Cathodoluminescence image of the crystal shown in (c), revealing two different generations of quartz. Note the coexistence of molybdenite (dashed lines) with brine inclusions $\left(B_{\text {STW }}\right)$ at the boundary between early quartz $\left(Q 1_{S T W}\right)$ and the late quartz $\left(Q 2_{S T W}\right)$ beryl veins, were studied using standard techniques for petrography (microscopy and SEM-CL imaging) and microthermometry. Petrographic fluid inclusion assemblages were selected for further analysis (Figs. 3 and 4). For clarity, petrographic observations and fluid inclusion results are described together for each of the different stages. (Tables 1, 2 and Fig. 5).

Fluid inclusion quality strongly depends on the location of the sample within the MHBX and the stockwork veins. The igneous and the transitional parts of the MHBX host only very small inclusions that are poorly preserved. Larger inclusions $(>10 \mu \mathrm{m})$ commonly showed decrepitation features, such as irregular, flat shape or halos of tiny inclusions around larger ones. Deformation seems to have destroyed the majority of the inclusions and only very small $(<10 \mu \mathrm{m})$ inclusions may have survived. In deformed parts the quartz has a lamellar appearance from tiny, stringed fluid inclusions. The best preserved fluid inclusions were found in the vuggy zone " $D$ " of the hydrothermal part of the MHBX, where quartz crystals grew into open space and in the stockwork veins, where the quartz was protected by molybdenite from later deformation.

Fluid inclusions in the deep MHBX (igneous matrix)

In the deeper, igneous part of the MHBX, only very small $(<15 \mu \mathrm{m})$, two-phase inclusions were found. These inclusions have bubbles occupying between $40 \%$ and $60 \%$ of the inclusion volume and contain no daughter crystals. The two-phase inclusions from the deeper part of the MHBX show highly variable microthermometric behaviour (not tabulated). Final ice melting temperatures range between $0.5^{\circ} \mathrm{C}$ and $-4.3^{\circ} \mathrm{C}$, and final clathrate melting occurs from about $6^{\circ} \mathrm{C}$ to $9.3^{\circ} \mathrm{C}$. These measurements constrain the salinities to between 1 and 7.5 wt. $\% \mathrm{NaCl}_{\text {equiv. }}$ The homogenisation temperature was not determined in light of the variable bubble sizes, even among apparently coeval inclusions.

Fluid inclusions in the upper MHBX (hydrothermal matrix)

Cathodoluminescence (SEM-CL) images reveal three generations of quartz (Fig. 3). The oldest generation appears light grey and unzoned $\left(\mathrm{Q} 1_{\mathrm{MHBX}}\right)$. This generation often hosts clusters of intermediate-density inclusions ( $\mathrm{ID}_{\mathrm{MHBX}}$ ) of possibly primary origin. This quartz $\mathrm{Q} 1_{\mathrm{MHBX}}$ is overgrown by idiomorphically growth-zoned Q2 $\mathrm{MHBX}$ quartz. This $\mathrm{Q} 2_{\mathrm{MHBX}}$ quartz also fills secondary cracks in $\mathrm{Q} 1_{\mathrm{MHBX}}$ and contains inclusions of type $\mathrm{B}_{\mathrm{MHBX}}$ (brine) and $\mathrm{V}_{\mathrm{MHBX}}$ (vapour). The youngest quartz generation ( $\mathrm{Q} 3_{\mathrm{MHBX}}$ ) occurs as thin SEM-CL black overgrowths, crack fillings and spots mainly in $\mathrm{Q} 1_{\mathrm{MHBX}}$ interpreted to represent decrepitated fluid inclusions (Fig. 3). Molybdenite inclusions 
Fig. 4 Photomicrographs of fluid inclusions of the different types and generations of fluids present in the magmatichydrothermal breccia (MHBX) and the later stockwork veins (STW) of the Questa porphyry Mo deposit as detailed in the text

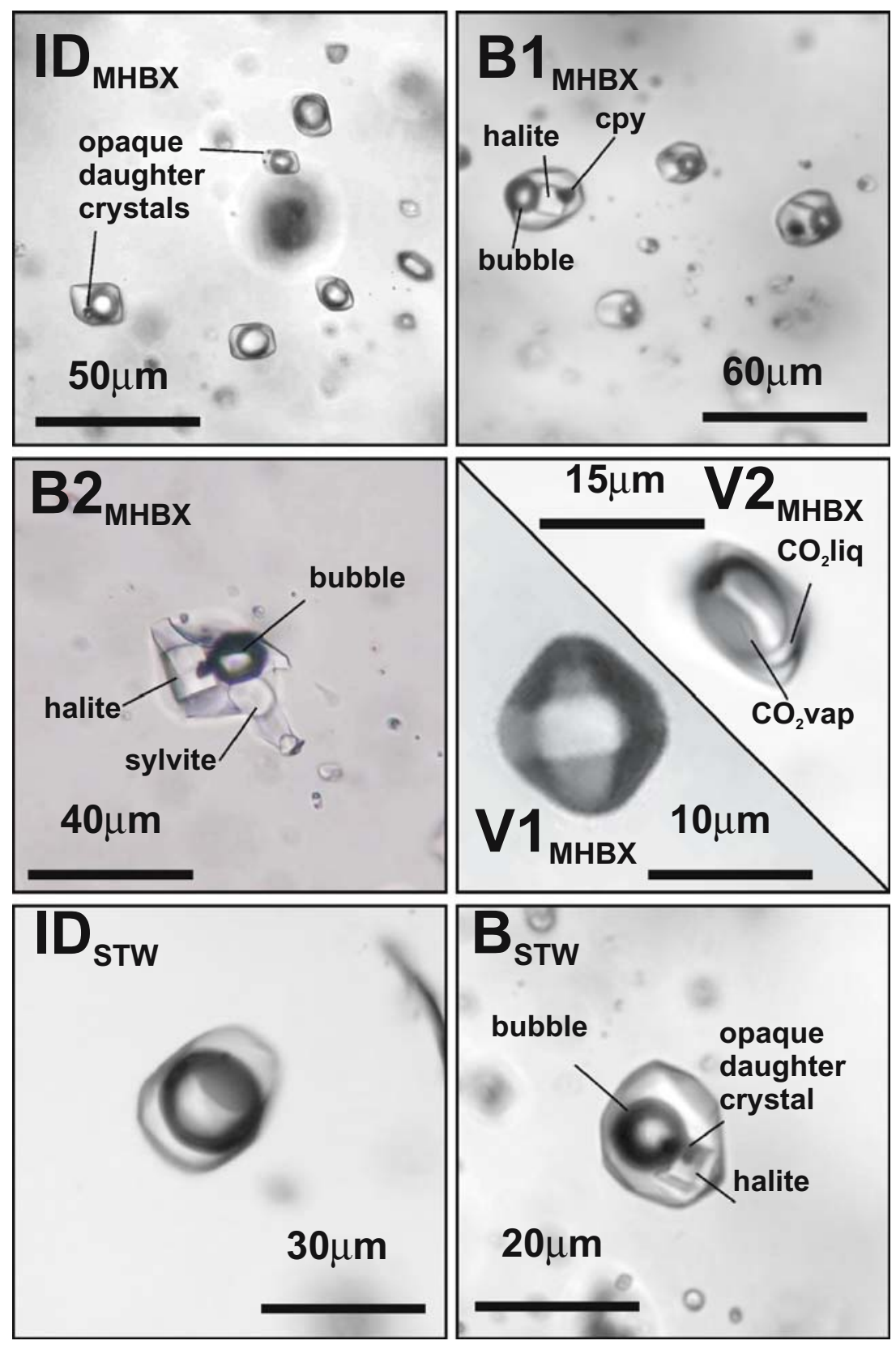

observed in other quartz crystals of the same samples line the contact between $\mathrm{Q} 2_{\mathrm{MHBX}}$ and $\mathrm{Q} 3_{\mathrm{MHBX}}$. All fluid inclusions studied in the MHBX samples were hosted by $\mathrm{Q} 1_{\mathrm{MHBX}}$ and $\mathrm{Q} 2_{\mathrm{MHBX}}$.

The intermediate-density fluid inclusions ( ID $_{\mathrm{MHBX}}$; Fig. 4) commonly occur in $\mathrm{Q} 1_{\mathrm{MHBX}}$ quartz. The $\mathrm{ID}_{\mathrm{MHBX}}$ inclusions are typically negative crystal shaped, isometric and between 10 and $20 \mu \mathrm{m}$ in diameter. They have a vapour bubble ( vol $_{\text {bubble }} \sim 50 \%$ ) and one opaque daughter crystal. The presence of $\mathrm{CO}_{2}$ is revealed in most cases as clathrate at low temperatures, but liquid $\mathrm{CO}_{2}$ is only rarely observed. Microthermometric behaviour of inclusions within well-defined petrographic assemblages reveals inconsistencies: some inclusions showed clathrate melting, others only melting of ice. Clathrate melting temperatures of $+7.6 \pm 0.9^{\circ} \mathrm{C}$ correspond to minimum salinities of $4.7 \pm$ 1.7 wt. $\% \mathrm{NaCl}_{\text {equiv }}$ (Diamond 1992). These are minimum salinities because no liquid $\mathrm{CO}_{2}$ in the inclusion was observed. Final ice melting temperatures of inclusions, where no clathrate was observed, average at $-4.6 \pm 0.6^{\circ} \mathrm{C}$ and indicate a salinity of $7.3 \pm 0.8 \mathrm{wt} . \% \mathrm{NaCl}_{\text {equiv. }}$ This combined evidence, thus, suggests that the "true" salinity of the $\mathrm{ID}_{\text {MHBX }}$ fluid is likely to be around $7 \mathrm{wt} . \%$ $\mathrm{NaCl}_{\text {equiv. }}$ Total homogenisation, occurring both to the liquid and to the vapour phase, is observed at $396 \pm 37^{\circ} \mathrm{C}$ (individual assemblage averages are reported in Table 2). 
Table 1 Stages of mineralisation in the Questa porphyry Mo deposit. Mineralogy, wall rock alteration and fluid inclusions as used for this study

\begin{tabular}{|c|c|c|c|c|}
\hline Stages & Mineralogy & Alteration & & Fluid inclusions (FI) \\
\hline \multirow[t]{4}{*}{$\begin{array}{l}\text { Magmatic-hydrothermal } \\
\text { breccia }(\mathrm{MHBX})\end{array}$} & \multirow{4}{*}{$\begin{array}{l}\text { Quartz, phlogopite, molybdenite, } \\
\text { anhydrite, K-feldspar, rutile, aplite, } \\
\text { (apatite and calcite = late?) }\end{array}$} & \multirow[t]{4}{*}{ Potassic (biotite) } & $\mathrm{ID}_{\text {MHBX }}$ & $\begin{array}{l}\text { Earliest FI's; intermediate-density, } \\
\text { low-salinity }\end{array}$ \\
\hline & & & $\mathrm{B} 1_{\mathrm{MHBX}}$ & $\begin{array}{l}\text { "Fresh" brine inclusions; halite }+ \\
\text { opaque daughter crystals }\end{array}$ \\
\hline & & & $\mathrm{B} 2_{\mathrm{MHBX}}$ & $\begin{array}{l}\text { "Stressed" brine inclusions; halite }+ \\
\text { sylvite + hematite + opaques }\end{array}$ \\
\hline & & & $\mathrm{V}_{\text {MHBX }}$ & $\begin{array}{l}\text { Vapour inclusions; similar to } \mathrm{ID}_{\mathrm{MHBX}} \text {, } \\
\text { but on boiling trails }\end{array}$ \\
\hline \multirow[t]{3}{*}{ Stockwork veins (STW) } & \multirow[t]{3}{*}{ Quartz, molybdenite, anhydrite, fluorite } & \multirow[t]{3}{*}{ Argillic? } & $\mathrm{ID}_{\mathrm{STW}}$ & $\begin{array}{l}\text { Earliest FI's in STW; intermediate- } \\
\text { density, low-salinity }\end{array}$ \\
\hline & & & $\mathrm{B}_{\mathrm{STW}}$ & $\begin{array}{l}\text { brine inclusions; halite }+ \\
\text { opaque daughter crystals }\end{array}$ \\
\hline & & & $\mathrm{V}_{\text {STW }}$ & $\begin{array}{l}\text { Vapour inclusions; similar to } \text { ID }_{\mathrm{STW}} \\
\text { but on boiling trails }\end{array}$ \\
\hline Beryl veins & $\begin{array}{l}\text { Quartz, beryl, fluorite, carbonates, } \\
\text { (scheelite, chalcopyrite, sulphosalts? }\end{array}$ & Not visible & $\mathrm{A}_{\mathrm{BERYL}}$ & Aqueous, low-salinity \\
\hline
\end{tabular}

ID Intermediate-density fluid inclusions, $B$ brine inclusions, $V$ vapour inclusions, $A$ aqueous inclusions

Brine inclusions (Fig. 4) occur as clusters and occasionally on pseudosecondary trails in Q1 $1_{\mathrm{MHBX}}$ quartz but can be assigned to Q2 $2_{\text {MHBX }}$ quartz based on SEM-CL images. Petrographically, they can be subdivided into two groups. At room temperature, $\mathrm{B} 1_{\mathrm{MHBX}}$ brine inclusions have halite and one or two opaque daughter crystals (chalcopyrite, molybdenite); $\mathrm{B} 2_{\mathrm{MHBX}}$ brines have halite, sylvite, a transparent birefringent mineral, opaque daughter crystals and, occasionally, hematite. The latter inclusions are commonly irregularly shaped and flat, whereas $\mathrm{B} 1_{\mathrm{MHBX}}$ inclusions usually have negative crystal shape. All brine inclusions are generally smaller than $30 \mu \mathrm{m}$ and have vapour bubbles of 10-20 vol.\%. The brine inclusions also show inconsistent microthermometric behaviour within petrographic inclusion assemblages: homogenisation by vapour bubble disappearance $\left(\mathrm{B} 1_{\mathrm{MHBX}}\right)$ as well as by halite dissolution ( $\left.\mathrm{B} 2_{\mathrm{MHBX}}\right)$ is observed in single inclusion trails (Table 2). For $\mathrm{B} 1_{\mathrm{MHBX}}$ and $\mathrm{B} 2_{\mathrm{MHBX}}$ brines the temperatures of final melting of halite are $293 \pm 62^{\circ} \mathrm{C}$ and $390 \pm 38^{\circ} \mathrm{C}$, respectively, indicating salinities of $38.2 \pm 4.6$ and $46.6 \pm 3.6 \mathrm{wt} . \% \mathrm{NaCl}_{\text {equiv. }}$. The bubble point transitions of $\mathrm{B} 1_{\mathrm{MHBX}}$ are at $406 \pm 31^{\circ} \mathrm{C}$, those of $\mathrm{B} 2_{\mathrm{MHBX}}$ at $340 \pm$ $36^{\circ} \mathrm{C}$.

Vapour inclusions (Fig. 4) cluster in two groups, $\mathrm{V} 1_{\text {MHBX }}$ and $\mathrm{V} 2_{\text {MHBX }} \cdot \mathrm{V} 1_{\text {MHBX }}$ inclusions have large bubbles $>90$ vol.\%, while the bubble size of $\mathrm{V} 2_{\mathrm{MHBX}}$ inclusions is smaller (70 vol.\%). No daughter crystals are visible. Vapour inclusions commonly have negative crystal shape and range between 5 and $20 \mu \mathrm{m}$. In $\mathrm{V} 2_{\mathrm{MHBX}}$ inclusions, liquid $\mathrm{CO}_{2}$ can sometimes be observed. $\mathrm{V} 2_{\mathrm{MHBX}}$-type inclusions are very similar to $\mathrm{ID}_{\mathrm{MHBX}}$ inclusions in terms of shape and phase proportions and could only be positively identified by their petrographic occurrence within the crystal, i.e. on clear pseudosecondary trails or in boiling assemblages. Vapour inclusions could be measured only in a few cases reliably by microthermometry because of difficulties in observing phase boundaries. Approximate homogenisation temperatures of $\mathrm{V} 2_{\mathrm{MHBX}}$ inclusions co-existing with $\mathrm{B} 2_{\mathrm{MHBX}}$ are $390^{\circ} \mathrm{C}$; salinities derived from final melting of ice at $-2.3 \pm 0.1^{\circ} \mathrm{C}$ are $3.9 \pm 0.2$ wt. $\% \mathrm{NaCl}_{\text {equiv. }}$, but those may well be elevated due to coentrapment of some brine.

Coexisting brine and vapour inclusions $\left(\mathrm{B} 1_{\mathrm{MHBX}}+\right.$ $\mathrm{V} 1_{\mathrm{MHBX}}$ and $\left.\mathrm{B} 2_{\mathrm{MHBX}}+\mathrm{V} 2_{\mathrm{MHBX}}\right)$ on secondary inclusion trails were commonly observed, but unambiguous boiling trail inclusions are typically too small $(<5 \mu \mathrm{m})$ for precise microthermometry. Brine inclusions on boiling trails commonly homogenise by halite dissolution except for one assemblage where total homogenisation happened at $424 \pm$ $38^{\circ} \mathrm{C}$ by bubble disappearance.

\section{Fluid inclusions in the stockwork veins}

The stockwork veins cutting the MHBX have fluid inclusions preserved only where molybdenite protected the quartz crystals from deformation; in quartz without molybdenite fluid inclusions are flat and irregularly shaped. Similar to the quartz from the MHBX, growth zones visible with SEM-CL distinguish two generations of quartz $\left(\mathrm{Q} 1_{\mathrm{STW}}\right.$ and $\mathrm{Q} 2_{\mathrm{STW}}$; Fig. 3). The older quartz $\mathrm{Q} 1_{\mathrm{STW}}$ appears light grey and sometimes slightly zoned in the centre and base of the crystals. It is overgrown by darker grey and conspicuously zoned $\mathrm{Q} 2_{\mathrm{STW}}$ quartz that is associated with molybdenite crystallisation. This same Q2 ${ }_{\text {STW }}$ quartz also occurs as crack fillings cutting Q1 $1_{\text {STW }}$ growth zonation. Primary intermediate-density inclusions 
Table 2 Microthermometric data of fluid inclusion assemblages from the different stages of mineralisation

\begin{tabular}{|c|c|c|c|c|c|c|c|c|c|c|c|c|c|c|c|c|c|}
\hline & Boiling & $\mathrm{T}_{\mathrm{m}} \mathrm{CO}_{2}$ & $\begin{array}{l}\mathrm{SD} \\
(N)\end{array}$ & $\begin{array}{l}\mathrm{T}_{\mathrm{m}} \\
\text { clath }\end{array}$ & $\begin{array}{l}\text { SD } \\
(N)\end{array}$ & $\mathrm{T}_{\mathrm{m}}$ ice & $\begin{array}{l}\mathrm{SD} \\
(N)\end{array}$ & $\mathrm{T}_{\mathrm{h}} \mathrm{H}_{2} \mathrm{O}$ & & $\begin{array}{l}\text { SD } \\
(N)\end{array}$ & $\begin{array}{l}\mathrm{T}_{\mathrm{m}} \\
\text { sylv }\end{array}$ & $\operatorname{SD}(N)$ & $\mathrm{T}_{\mathrm{m}}$ hal & $\begin{array}{l}\mathrm{SD} \\
(N)\end{array}$ & $\begin{array}{l}\text { wt.\% } \\
\mathrm{NaCl}_{\text {equiv. }}\end{array}$ & $\begin{array}{l}S D \\
(N)\end{array}$ & $\begin{array}{l}\text { LA- } \\
\text { ICPMS }\end{array}$ \\
\hline \multicolumn{18}{|l|}{ ID MHBX } \\
\hline 22-14-709-A1 & & n.o. & & n.o. & & -4.8 & $-(3)$ & 423 & $\mathrm{~L}$ & $-(3)$ & & & & & 7.6 & $-(3)$ & $\mathrm{X}$ \\
\hline $22-14-709-\mathrm{A} 2$ & & & & 7.0 & $-(3)$ & & & & & & & & & & 5.7 & $-(3)$ & $\mathrm{X}$ \\
\hline 22-14-709-A5 & & & & & & -3.0 & $0.3(4)$ & & & & & & & & 4.9 & $0.5(4)$ & $\mathrm{X}$ \\
\hline QD-2.2-A4 & & -57.4 & $-(4)$ & 5.4 & $1.7(5)$ & & & & & & & & & & 8.3 & $2.3(5)$ & $\mathrm{X}$ \\
\hline $22-14-709-\mathrm{A} 6$ & & -57.3 & $0.1(3)$ & 6.4 & $2.6(3)$ & & & & & & & & & & 6.6 & $4.2(3)$ & $\mathrm{X}$ \\
\hline 22-14-928-A1 & & & & & & -1.3 & $0.3(2)$ & & & & & & & & 2.2 & $0.5(2)$ & $\mathrm{X}$ \\
\hline $22-14-928-\mathrm{A} 2$ & & & & & & -2.0 & $1.2(3)$ & & & & & & & & 3.4 & $1.8(3)$ & $\mathrm{X}$ \\
\hline 22-14-928-A3 & & & & 7.3 & $0.8(4)$ & & & & & & & & & & 5.6 & $1.6(5)$ & $\mathrm{X}$ \\
\hline QDS-4.9-010 & & & & 4.6 & $1.1(3)$ & -5.1 & $-(1)$ & 305 & $\mathrm{~L}$ & $-(I)$ & & & & & 9.5 & $1.7(3)$ & $\mathrm{X}$ \\
\hline $22-14-709-\mathrm{A} 3+$ & & & & & & -2.3 & $0(2)$ & & & & & & & & 3.9 & $0(2)$ & $\mathrm{X}$ \\
\hline \multicolumn{18}{|l|}{ B1 MHBX } \\
\hline $22-14-870-2 b-A 2$ & & & & & & & & 361 & $\mathrm{~L}$ & $16(7)$ & n.o. & & 280 & $49(7)$ & 37 & $3(7)$ & $\mathrm{X}$ \\
\hline QD-2.2-A1 & & & & & & & & 396 & $\mathrm{~L}$ & $10(2)$ & n.o. & & 374 & $13(2)$ & 45 & $1(2)$ & $\mathrm{X}$ \\
\hline QD-2.2-A3 & & & & & & & & 396 & $\mathrm{~L}$ & $10(2)$ & n.o. & & 374 & $13(2)$ & 45 & $1(2)$ & $\mathrm{X}$ \\
\hline $22-14-709-\mathrm{A} 3$ & & & & & & & & 427 & $\mathrm{~L}$ & $17(11)$ & n.o. & & 340 & $24(11)$ & 42 & $2(11)$ & $\mathrm{X}$ \\
\hline QDS-4.9-002-A1 & & & & & & & & 408 & $\mathrm{~L}$ & $17(7)$ & n.o. & & 220 & $43(7)$ & 33 & $3(7)$ & $\mathrm{X}$ \\
\hline QDS-4.9-002-A2 & & & & & & & & 391 & $\mathrm{~L}$ & $10(5)$ & n.o. & & 305 & $50(5)$ & 39 & $4(5)$ & $\mathrm{X}$ \\
\hline 2-14-709-A7 & & & & & & & & 429 & $\mathrm{~L}$ & $30(2)$ & 115 & $-(l)$ & 388 & $15(2)$ & 46 & $2(2)$ & \\
\hline 22-14-709-A8 & $X$ & & & & & & & 424 & $\mathrm{~L}$ & $38(8)$ & n.o. & & 248 & $44(8)$ & 35 & $3(8)$ & \\
\hline $22-14-729 \mathrm{c}-\mathrm{A} 1$ & & & & & & & & 396 & $\mathrm{~L}$ & $9(3)$ & n.o. & & 298 & $53(3)$ & 38 & $4(3)$ & \\
\hline \multicolumn{18}{|l|}{ B2 MHBX } \\
\hline 22-14-740a-A3 & & & & & & & & 360 & $\mathrm{~L}$ & $17(7)$ & n.m. & & 419 & $8(7)$ & 50 & $1(7)$ & \\
\hline 22-14-740a-A2 & & & & & & & & 343 & $\mathrm{~L}$ & $11(5)$ & 211 & $-(1)$ & 414 & $9(5)$ & 49 & $1(5)$ & \\
\hline $22-14-870-2 b-A 2$ & & & & & & & & 355 & $\mathrm{~L}$ & $35(3)$ & n.m. & & 384 & $5(3)$ & 46 & $1(3)$ & \\
\hline QD-2.2-A3 & & & & & & & & 356 & $\mathrm{~L}$ & $18(3)$ & n.m. & & 403 & $7(3)$ & 47 & $1(3)$ & \\
\hline $22-14-709-\mathrm{A} 3$ & & & & & & & & 393 & $\mathrm{~L}$ & $2(3)$ & n.m. & & 408 & $6(3)$ & 48 & $1(3)$ & \\
\hline QDS-4.9-007 & & & & & & & & 319 & $\mathrm{~L}$ & $15(9)$ & n.m. & & 378 & $28(9)$ & 45 & $3(9)$ & $\mathrm{X}$ \\
\hline QDS-4.9-010-A2 & & & & & & & & 271 & $\mathrm{~L}$ & $46(3)$ & n.m. & & 298 & $38(3)$ & 38 & $3(3)$ & \\
\hline \multicolumn{18}{|l|}{ V MHBX } \\
\hline QD-2.2-A5 & & n.o. & & n.o. & & -2.3 & $0.1(2)$ & 387 & $\mathrm{~V}$ & $2(2)$ & & & & & 3.9 & $0.2(2)$ & $\mathrm{X}$ \\
\hline \multicolumn{18}{|l|}{ ID STW } \\
\hline QDS-3-A3 & & & & & & -6.8 & & & & & & & & & 9.7 & $7.5(2)$ & $\mathrm{X}$ \\
\hline QDS-3.4-A2 & & & & & & -3.3 & & & & & & & & & 5.4 & $0.1(4)$ & $\mathrm{X}$ \\
\hline QDS-3-A1 & & & & & & -3.0 & & & & & & & & & 4.9 & $2.6(7)$ & $\mathrm{X}$ \\
\hline QDS-3-Ax & & & & 3.4 & $-(I)$ & -6.7 & $6.4(3)$ & 391 & $\mathrm{~L}$ & $6(2)$ & & & & & 9.8 & $6.4(4)$ & $\mathrm{X}$ \\
\hline QDS-4.9-007 & & n.o. & & n.o. & & -3.9 & $0.1(2)$ & 401 & $\mathrm{~L}$ & $2(2)$ & & & & & 2.0 & $0.2(4)$ & $\mathrm{X}$ \\
\hline \multicolumn{18}{|l|}{ B STW } \\
\hline QDS-3-A3 & & & & & & & & 321 & $\mathrm{~L}$ & $55(11)$ & & & 238 & $17(11)$ & 34 & $1(11)$ & $\mathrm{X}$ \\
\hline QDS-3.5 & $X$ & & & & & & & 354 & $\mathrm{~L}$ & $36(3)$ & & & 298 & $58(3)$ & 36 & $2(3)$ & $\mathrm{X}$ \\
\hline \multicolumn{18}{|l|}{ V STW } \\
\hline QDS-3.5 & $X$ & n.o. & & n.o. & & -1.6 & $0.5(13)$ & 392 & $\mathrm{~V}$ & $8(13)$ & & & & & 2.8 & $0.9(13)$ & $\mathrm{X}$ \\
\hline \multicolumn{18}{|l|}{ A BERYL } \\
\hline QDS-1-003 & & n.o. & & n.o. & & -2.5 & $0.2(8)$ & 376 & $\mathrm{~L}$ & $12(8)$ & & & & & 4.1 & $0.3(8)$ & \\
\hline
\end{tabular}

Values are assemblage averages in degrees Celsius, with 1 standard deviation (SD) and the number of significant values in brackets set italic $S D$ standard deviation, boiling brine and vapour inclusions co-existing in single assemblage $(X), T_{m 2}$ final melting temperature of $\mathrm{CO}_{2}, T_{m}$ clath final melting temperature of $\mathrm{CO}_{2}-\mathrm{H}_{2} \mathrm{O}$ clathrate, $T_{m}$ ice final melting temperature of ice, $T_{h 2} \mathrm{O}$ homogenisation temperature of the $\mathrm{H}_{2} \mathrm{O}$ phases, $T_{m}$ $s y l v$ final dissolution temperature of sylvite daughter crystal, $T_{m}$ hal final dissolution temperature of halite daughter crystal, $w t . \% \mathrm{NaCl}$ equiv salinity (weight $\% \mathrm{NaCl}$ equivalent), n.o. not observed, n.m. not measured, $L$ bubble point transition, $V$ dew-point transition, $L A$-ICPMS laser ablation ICPMS analysis available (X)

$\left(\mathrm{ID}_{\mathrm{STW}} ;\right.$ Fig. 4) are restricted to $\mathrm{Q} 1_{\mathrm{STw}}$. They show negative crystal shaped up to $40 \mu \mathrm{m}$ in length and have vapour bubbles of about $50-60$ vol.\% and one opaque daughter crystal. Final ice melting temperatures of $-1.2 \pm$ $0.1^{\circ} \mathrm{C}$ correspond to a salinity of $2.0 \pm 0.2 \mathrm{wt} . \% \mathrm{NaCl}_{\text {equiv }}$. Clathrate was observed in one inclusion only. The total homogenisation temperature of these inclusions is determined at $388 \pm 4^{\circ} \mathrm{C}$ (one assemblage; $N=5$ ).

Brine ( $\mathrm{B}_{\mathrm{STw}} ;$ Fig. 4$)$ and very rare vapour inclusions occur on pseudosecondary trails, which end on Q2 $\mathrm{STw}$ growth zones lined with primary brine inclusions and with solid molybdenite inclusions. The brines have a halite and usually a chalcopyrite daughter crystal. Negative-crystal shaped brine inclusions are usually 10 to $20 \mu \mathrm{m}$ in diameter. The bubble occupies $10-20$ vol. $\%$ at room temperature. Brine inclusions have final halite melting temperatures of $251 \pm 37^{\circ} \mathrm{C}$, which indicates salinities of $34.3 \pm 1.3$ wt.\% $\mathrm{NaCl}_{\text {equiv. }}$. Homogenisation temperatures are $328 \pm 52^{\circ} \mathrm{C}$ on average, generally occurring by vapour bubble disappearance. Unequivocal vapour inclusions have 
Fig. 5 Summary plot of the microthermometric measurements of all fluid inclusion types. Individual inclusion types are grouped for the two mineralisation stages, the magmatichydrothermal breccia (MHBX) and the later stockwork veins (STW). A few "outliers" have been omitted from this plot

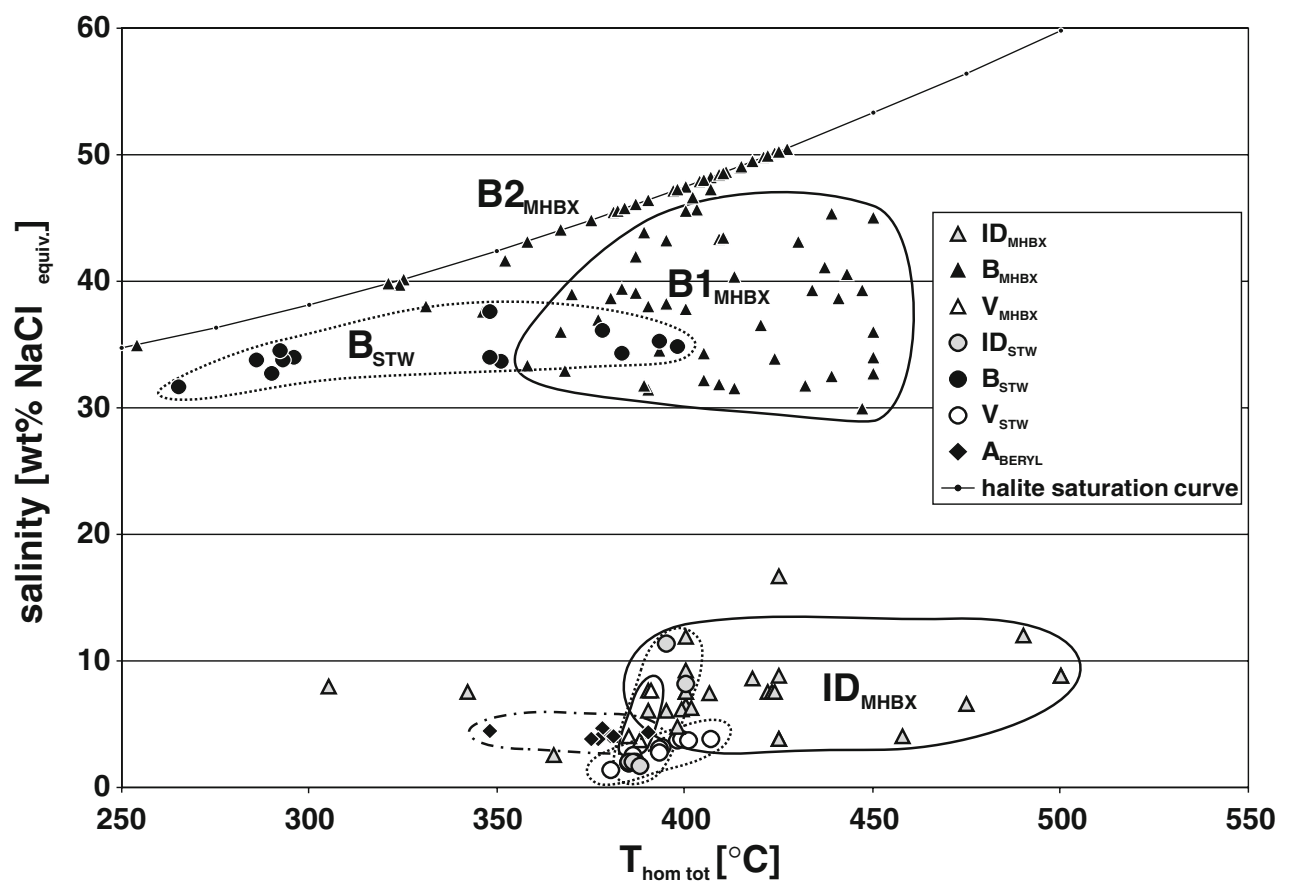

only been found in one boiling assemblage and revealed total homogenisation by bubble expansion at $392 \pm 8^{\circ} \mathrm{C}(N=$ 13). They have salinities of $2.8 \pm 0.9 \mathrm{wt} . \%$ on average (final melting of ice at $-1.6 \pm 0.5^{\circ} \mathrm{C}$ ).

Fluid inclusions in the quartz-beryl veins

In these post-ore veins only beryl preserves primary aqueous inclusions of usable size $(10-30 \mu \mathrm{m})$ on growth zones. Inclusions have vapour bubbles of 10 to 20 vol.\% and contain no daughter minerals. Final melting of ice at $-2.5 \pm 0.2^{\circ} \mathrm{C}$ indicates a salinity of $4.1 \pm 0.5 \mathrm{wt} . \% \mathrm{NaCl}_{\text {equiv. }}$. Total homogenisation to the liquid phase occurs at $376 \pm$ $12^{\circ} \mathrm{C}$.

\section{LA-ICPMS analysis of fluid inclusions}

Fluid inclusions from the MHBX and the stockwork vein stage were analysed by LA-ICPMS. Average element concentrations of assemblages are summarised in Table 3, and the complete data set for each individual inclusion is reported in the "Electronic supplementary material". Generally, $\mathrm{Na}, \mathrm{K}, \mathrm{Mn}$ and $\mathrm{Fe}$ are the major elements in the fluid inclusions of all types and locations. Notable is a relatively high $\mathrm{Cu}$ concentration in most of the fluids, contrasting with the very minor amount of $\mathrm{Cu}$-bearing minerals in the deposit. The reproducibility of element ratios within fluid inclusion assemblages is good for most elements $(\sim 20 \%$ at one standard deviation); however, larger variations are observed for some ore metals.
MHBX upper part (vuggy, hydrothermal matrix)

In $\mathrm{ID}_{\mathrm{MHBX}}$ fluid inclusion assemblages, $\mathrm{Na}, \mathrm{K}$ and $\mathrm{Fe}$ are the major cations. The average Mo concentrations are between 16 and $90 \mu \mathrm{g} / \mathrm{g}$; the $\mathrm{Cu}$ concentrations vary between 200 and $5,000 \mu \mathrm{g} / \mathrm{g}$. The brine inclusions $\left(\mathrm{B} 1_{\mathrm{MHBX}}\right)$ contain $\mathrm{Na}, \mathrm{K}, \mathrm{Mn}$ and $\mathrm{Fe}$ with concentrations higher than $1 \mathrm{wt} . \%$. Molybdenum is highly variable from $1100 \mu \mathrm{g} / \mathrm{g}$ to values below the LOD of $\sim 5 \mu \mathrm{g} / \mathrm{g}$ in individual inclusions; average concentrations for individual assemblages lie between 85 and $470 \mu \mathrm{g} / \mathrm{g}$. Copper ranges between 870 and $7700 \mu \mathrm{g} / \mathrm{g}$. Only a few vapour inclusions could be analysed. They are enriched in $\mathrm{B}, \mathrm{Cu}$ and $\mathrm{As}$ relative to the brines. Molybdenum is present in concentrations of around $65 \mu \mathrm{g} / \mathrm{g}$.

Analyses of fluid inclusions from the deeper parts of the MHBX (igneous matrix) gave relatively high LOD because of their small size $(<10 \mu \mathrm{m})$. Therefore, partial data were obtained for most elements only (reported only in the "Electronic supplementary material"), but these overlap entirely with intermediate-density fluids from the upper MHBX.

\section{Stockwork veins}

Remarkable is the approximately ten times higher Cs concentration of all fluid inclusions of the stockwork veins relative to the fluid inclusions from the earlier MHBX, while all other element abundances overlap between MHBX and STW samples. The intermediate-density fluid inclusions from the stockwork veins $\left(\mathrm{ID}_{\mathrm{STW}}\right)$ contain mainly $\mathrm{Na}, \mathrm{K}$, 
Mn and Fe. The average Mo concentrations are between 6 and $60 \mu \mathrm{g} / \mathrm{g}$. The brines ( $\left.\mathrm{B}_{\mathrm{STW}}\right)$ contain $\mathrm{Na}, \mathrm{K}, \mathrm{Mn}$ and $\mathrm{Fe}$ at concentrations higher than 1 wt.\%. Molybdenum is present at concentrations between 11 and $180 \mu \mathrm{g} / \mathrm{g} . \mathrm{Cu}$ ranges between 740 and $2,700 \mu \mathrm{g} / \mathrm{g}$. Vapour inclusions $\left(\mathrm{V}_{\mathrm{STW}}\right)$ are relatively enriched in $\mathrm{Cu}$. Elements such as B, As, Mo and Sn were below LOD.

Fluid inclusions in the beryl-bearing quartz veins

Fluid inclusions in quartz are poorly preserved and were not analysed. LA-ICPMS analysis of the fluid inclusions hosted in blue and green beryl did not give significant inclusion signals for these dilute fluids because of the high host mineral contents of the major fluid inclusion elements. The blue beryl itself contains about 1 wt.\% Fe, which is most probably responsible for its blue colour. The green beryl contains up to $1,000 \mu \mathrm{g} / \mathrm{g}$ of $\mathrm{Cr}$ probably acting as the colouring element. The LA-ICPMS data of the analyses of the beryl is reported in the "Electronic supplementary material".

\section{Discussion and interpretation}

Before interpreting the data obtained in this fluid inclusion study, it is necessary to evaluate the extent and effect of post-entrapment modification of fluid inclusion contents. This is followed by a chronological discussion of the genesis of the deposit, going back in time from molybdenite precipitation through the preceding process of fluid phase separation to the exsolution of the ore-forming fluids from a fractionating source magma.

\section{Post-entrapment modification of fluid inclusions}

A number of observations on petrographic fluid inclusion assemblages sensu stricto suggest that at least some fluid inclusion contents were modified after entrapment. Evidence for this includes the irregular, flat shape of some inclusions (Fig. 4), the highly variable salinities and the wide range of homogenisation temperatures derived from microthermometry of coevally entrapped inclusions (Table 2), the presence of brine inclusions homogenising by halite dissolution on boiling trails and the spotty areas of host quartz visible in SEM-CL images (Fig. 3).

Post-entrapment modification of fluid inclusions may result either in changes in bulk fluid inclusion density without loss of content (stretching or shrinkage; Roedder 1984) or a gain or loss of material which may change both fluid inclusion composition and bulk density (e.g. Audétat and Günther 1999). The homogenisation of $\mathrm{B} 2_{\mathrm{MHBX}}$ brines from unambiguous boiling assemblages by final dissolution of halite, several tens of degrees Celsius above the temperature of bubble disappearance, indicates that such inclusions in the MHBX suffered from either volume shrinkage at constant salinity or selective water loss at constant inclusion volume, or both. This is because the liquid limb of the solvus reaches halite saturation only at the univariant $\mathrm{H}+\mathrm{L}+\mathrm{V}$ curve, where halite and vapour should disappear together upon heating (Fig. 6; Driesner and Heinrich 2007). Cline and Bodnar (1994) had not observed any boiling trails at Questa and, therefore, argued that the brine inclusions homogenising through halite dissolution represent entrapment of a high-salinity singlephase fluid well above the two-phase surface, after it had exsolved directly from a silicate melt. This interpretation is based on the assumption that the brine inclusions retained their original composition as well as their bulk density. Here, we conclude that most of the inclusions homogenising by halite dissolution (Fig. 5), and possibly others, were modified in their composition and density after entrapment. Brine inclusions plotted in Fig. 5 indicate a weak trend from higher to lower homogenisation temperatures and from lower to higher salinities. This trend is consistent with an increase in density and bulk salinity due to post-entrapment loss of water (Audétat and Günther 1999). Accidental entrapment of halite may have a similar effect (elevated salinities and lowered $\mathrm{T}_{\mathrm{h} \text {,tot }}$ ) and was suggested by Rowe (2005) to explain total homogenisation of brine inclusions by halite dissolution. However, a large scatter in $\mathrm{Na} / \mathrm{K}$ ratios would be expected among all brine inclusions (i.e. excess $\mathrm{Na}$ in those which have trapped halite), but this is not evident $\left(\mathrm{Na} / \mathrm{K}_{\text {MHBX brines }}=1.77 \pm 0.67 ; \mathrm{Na} / \mathrm{K}_{\mathrm{STW} \text { brines }}=\right.$ $1.89 \pm 0.54$; cf. "Electronic supplementary material”).

Distinguishing well-preserved from modified inclusions has proven difficult because the extent of modification is variable and not a simple function of inclusion size and shape. Audétat and Günther (1999) demonstrated that postentrapment modification of magmatic-hydrothermal fluid inclusions mostly led to loss of $\mathrm{H}_{2} \mathrm{O}$, changing microthermometric properties (salinity, homogenisation behaviour). The metal ratios, however, remain largely unaffected except for $\mathrm{Li}$. This was also found in the present study, and we, therefore, base our interpretations primarily on analysed element ratios, rather than salinity-dependent element concentrations. For the same reason, estimates of entrapment temperature are based on the lowest $\mathrm{T}_{\mathrm{h} \text {,tot }}$ bubble point transitions of brine inclusions, because the total homogenisation by dew-point transition of vapour inclusions is impossible to observe reliably (Sterner and Bodnar 1989).

Intermediate-density and vapour inclusions are expected to have experienced less post-entrapment modifications due to their flatter isochores in PTX space, yet microthermometry reveals that even these inclusions may have been 


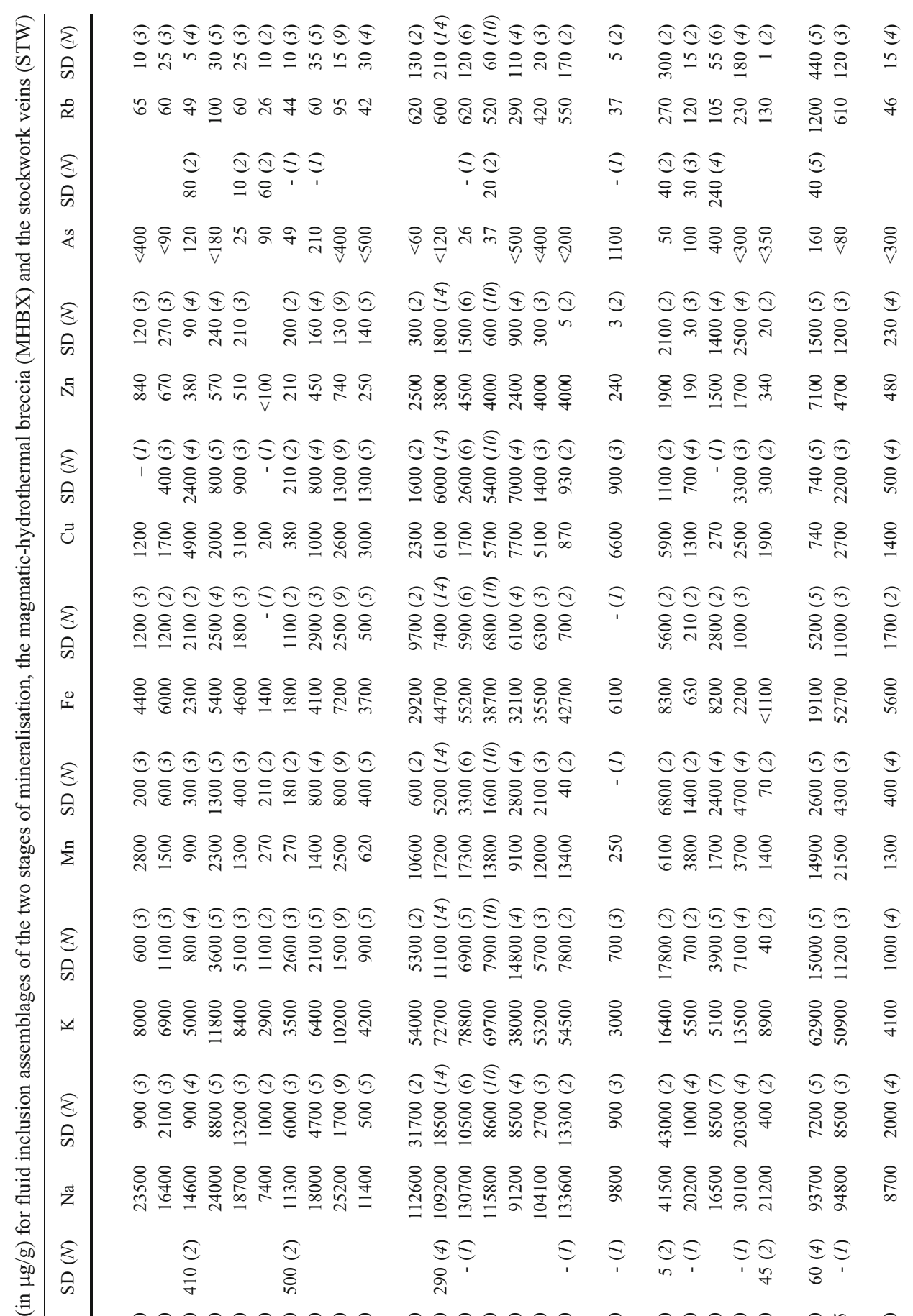

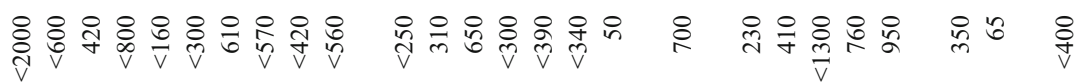

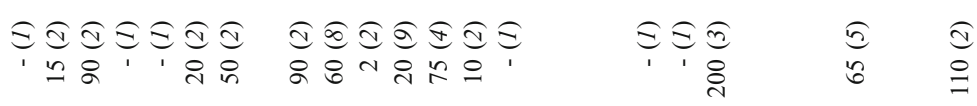

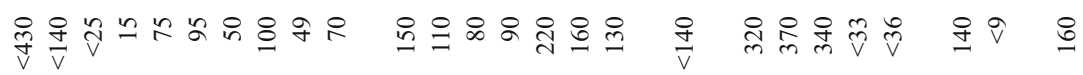

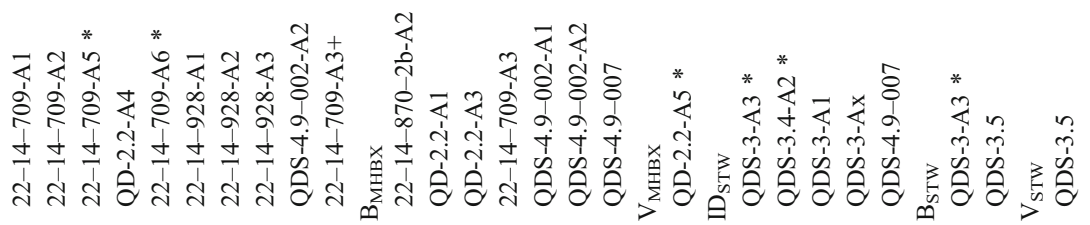




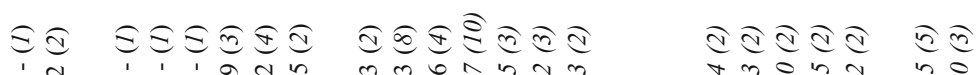

m

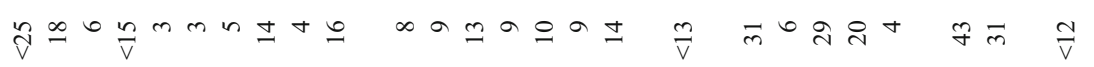

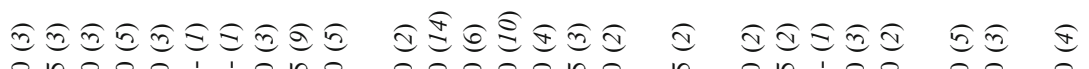

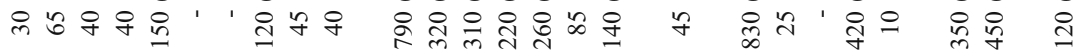

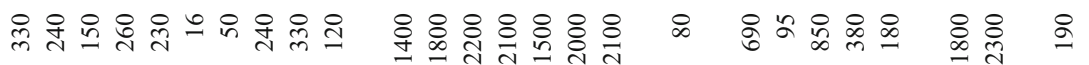

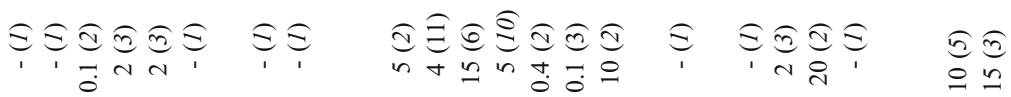

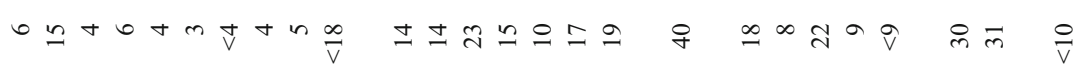

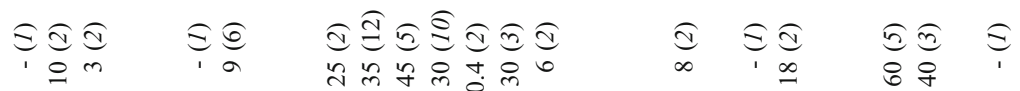

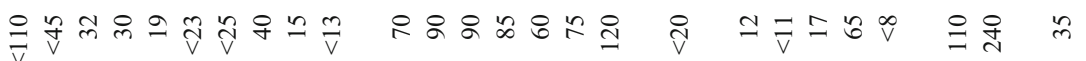

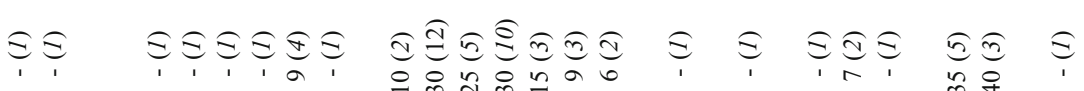

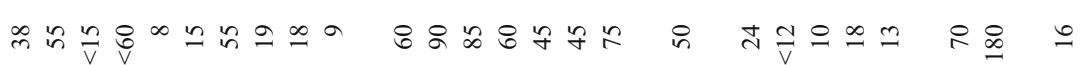

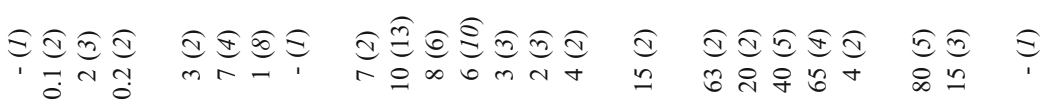

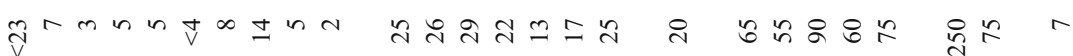

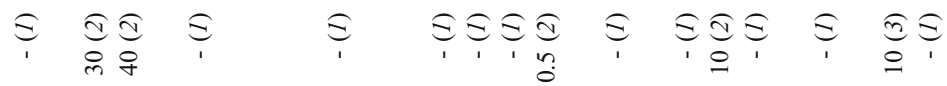

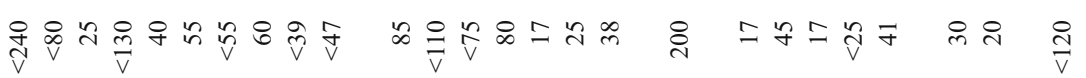

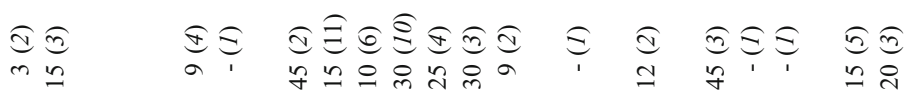

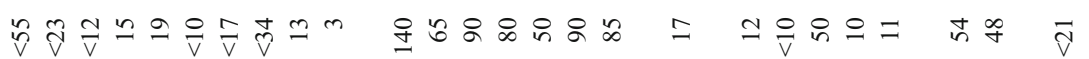

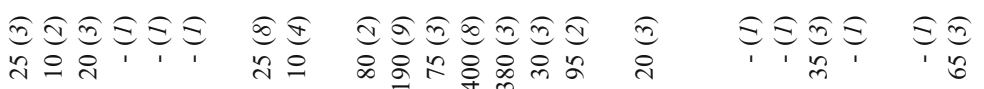

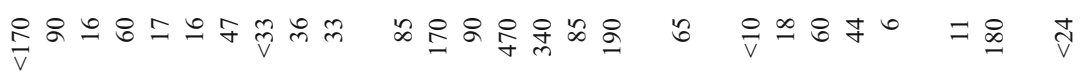

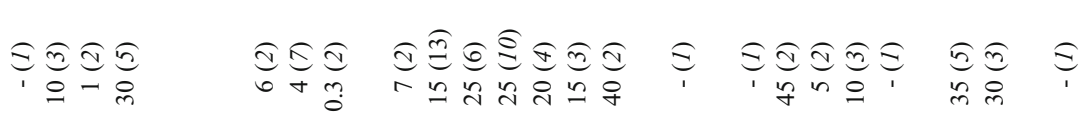

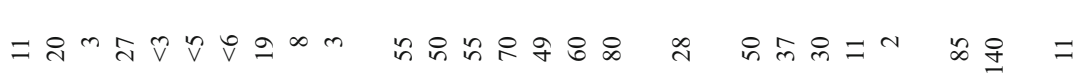

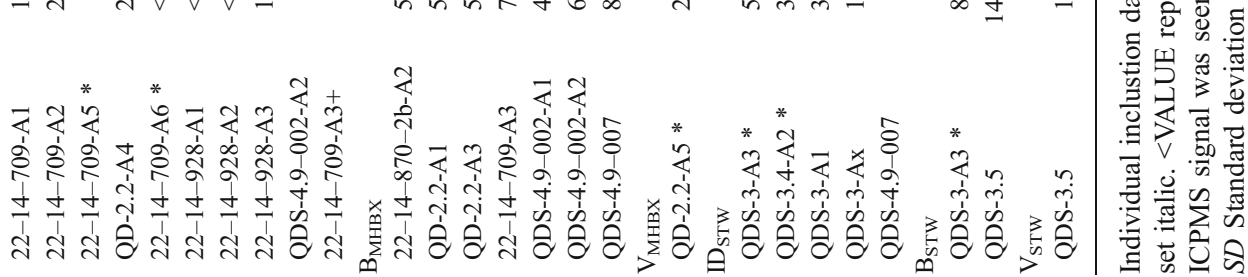


Fig. $6 \mathrm{NaCl}-\mathrm{H}_{2} \mathrm{O}$ P-T-X phase diagram (after Driesner and Heinrich 2007). The liquid + vapour coexistence surface is projected onto the $\mathrm{P}-\mathrm{X}$ plane and contoured for temperature. The liquid + halite coexistence boundary at $400^{\circ} \mathrm{C}$ is also shown. This figure summarises the evolutionary path of the fluids in the Questa porphyry Mo system. The effect of postentrapment modification affecting the brine populations of the early magmatic-hydrothermal breccia (MHBX), highlighted with a white arrow, may be the result of later heating associated with stockwork veining. Phase separation at $420^{\circ} \mathrm{C}$ translates into a fluid pressure of less than 280 bar during MHBX mineralisation

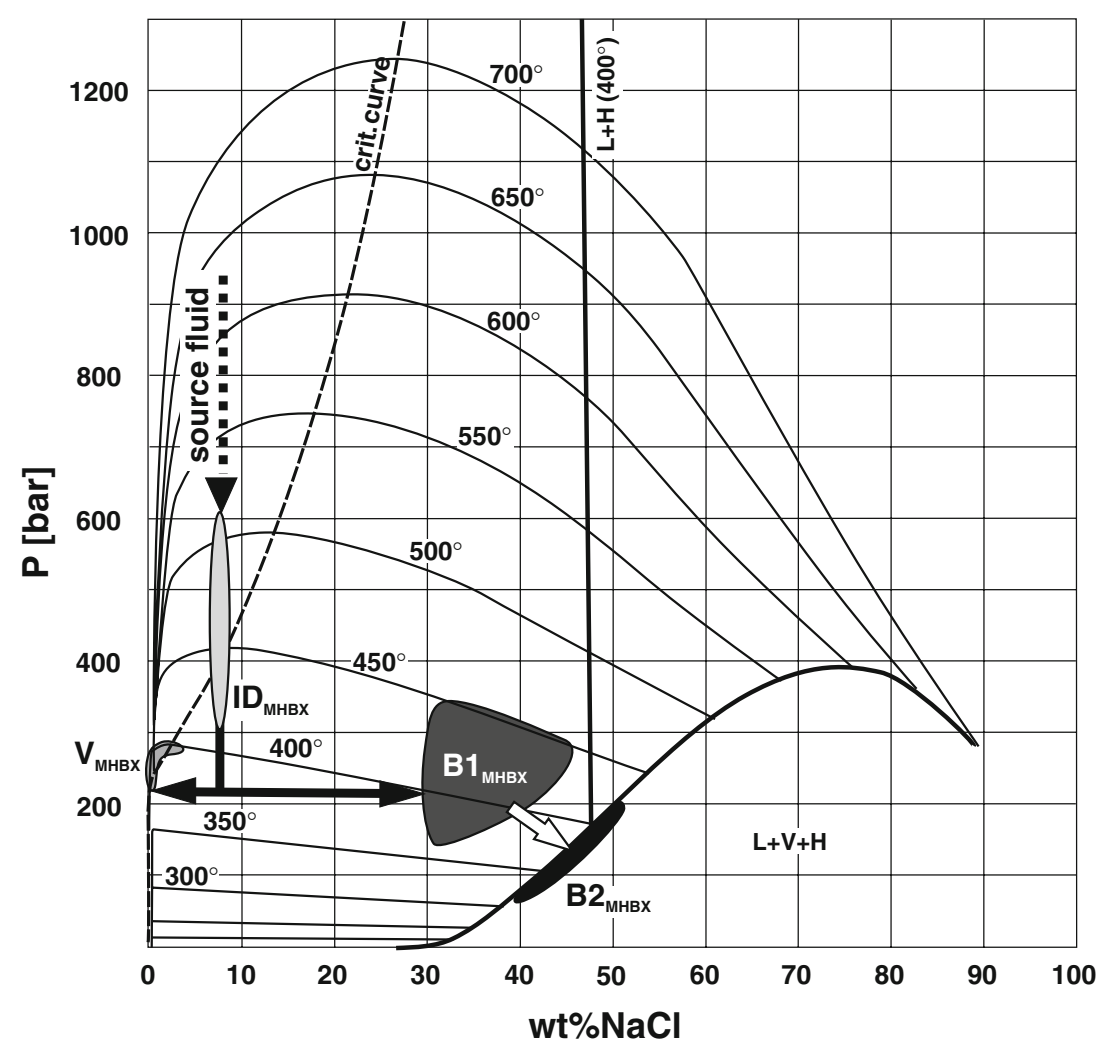

affected. Vapour inclusions of boiling assemblages generally have salinities higher than those expected from the binary $\mathrm{H}_{2} \mathrm{O}-\mathrm{NaCl}$ phase diagram and the microthermometric properties of the associated brine inclusions (Fig. 6). This observation might be accounted for by trapping variable proportions of brine in vapour inclusions due to preferred wetting of brine relative to vapour on quartz but may equally point to loss of $\mathrm{H}_{2} \mathrm{O}$, leaving behind a higher bulk salinity in the vapour inclusions. Therefore, the data derived from LA-ICPMS analyses of vapour inclusions are, again, interpreted as element ratios, with the possibility of some brine admixture.

Mineralisation stages, evolution of fluid chemistry and molybdenite precipitation

Two mineralisation events, the MHBX and the later stockwork veins (STW), each contributed comparably to the total economic Mo resource at Questa (Ross et al. 2002). The chemistry and evolution of the ore fluids of both stages are remarkably similar, except for distinctive Cs/ $(\mathrm{Na}+\mathrm{K}+\mathrm{Mn}+\mathrm{Fe})$ signatures reflecting a distinction of the two input fluids already prior to their arrival at the ore deposition site (Fig. 7; discussed below). Distinctive Cs/ $(\mathrm{Na}+\mathrm{K}+\mathrm{Mn}+\mathrm{Fe})$ ratios and systematically variable $\mathrm{Mo} /$ $(\mathrm{Na}+\mathrm{K}+\mathrm{Mn}+\mathrm{Fe})$ ratios show that the two stages of mineralisation represent separate pulses of magmatic- hydrothermal fluid, fluid batches that exsolved individually from a progressively more fractionated magma source.

Intermediate-density fluid inclusions ( $\mathrm{ID}_{\mathrm{MHBX}}$ and $\left.\mathrm{ID}_{\mathrm{STW}}\right)$ in early quartz generations followed by petrographically later boiling assemblages suggest that brine $\left(\mathrm{B} 1_{\mathrm{MHBX}}\right.$ and $\left.\mathrm{B}_{\mathrm{STW}}\right)$ and vapour separated from a single-phase fluid of intermediate-density, as a result of cooling and decompression of the hydrothermal system during each mineralisation stage. Boiling assemblages constrain temperatures of entrapment to about $420^{\circ} \mathrm{C}$ for both mineralisation stages. For phase separation to take place at $420^{\circ} \mathrm{C}$, a single-phase fluid with $\sim 7$ wt. $\% \mathrm{NaCl}_{\text {equiv }}$ intersects the two-phase surface close to the critical curve on the liquidlike side of the two-phase surface at a pressure of about 280 bar, taking the $\mathrm{H}_{2} \mathrm{O}-\mathrm{NaCl}$ model system for reference (Fig. 6; Driesner and Heinrich 2007). At a depth of 3,100 to $5,300 \mathrm{~m}$ constrained by stratigraphic reconstruction of the volcanic pile (Molling 1989), a pressure of 280 bar would correspond to a fluid column with an average fluid density of 0.90 to $0.53 \mathrm{~g} / \mathrm{cm}^{3}$, i.e. the recorded pressure is consistent with approximately hydrostatic conditions during Mo deposition.

Intermediate-density inclusions in the MHBX ( $\operatorname{ID}_{\mathrm{MHBX}}$ ) have an average Mo concentration of $42 \pm 28 \mu \mathrm{g} / \mathrm{g}$ (average over all $\mathrm{ID}_{\mathrm{MHBX}}$ inclusions, see "Electronic supplementary material"), indistinguishable from that of later stockwork veins (ID STw $_{36} \pm 30 \mu \mathrm{g} / \mathrm{g}$ ). Maximum values up to 
Fig. 7 Concentrations of molybdenum against $\mathrm{Cs}$, normalised to the sum of main elements $(\mathrm{Na}+\mathrm{K}+\mathrm{Mn}+\mathrm{Fe})$ of the fluids, linking the hydrothermal evolution at the level of the deposit to the evolution of the source magma at depth. Silicate melt inclusions from miarolitic cavities from barren intrusions within the Questa caldera (Audétat and Pettke 2003) define a melt fractionation trend. Early stage ID inclusions from the magmatic-hydrothermal breccia (MHBX) and the later stockwork veins (STW) lie on a weak trend parallel to the melt trend (yellow and light-blue arrows). This implies that the STW stage evolved from a more fractionated magma than did the MHBX stage. Brine inclusions from both stages of mineralisation show decreasing $\mathrm{Mo} /(\mathrm{Na}+\mathrm{K}+\mathrm{Mn}+\mathrm{Fe})$ at constant $\mathrm{Cs} / \mathrm{Na}+\mathrm{K}+\mathrm{Mn}+$ $\mathrm{Fe})$, highlighted by vertical red $(M H B X)$ and blue (STW) arrows, reflecting molybdenite precipitation (compare Fig. 8)
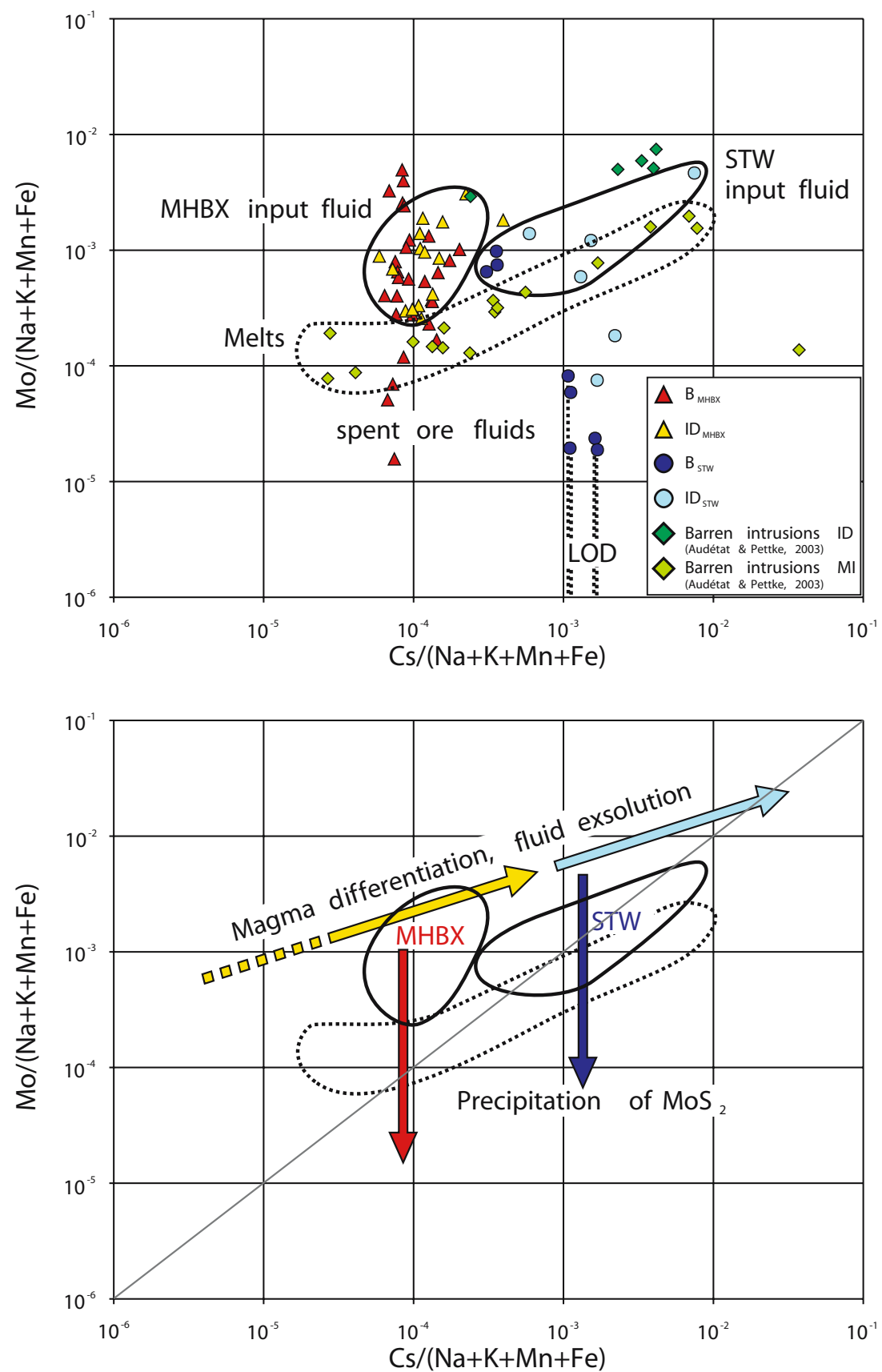

$\sim 100 \mu \mathrm{g} / \mathrm{g}$ in both stages may be closer to the actual input concentration, however, if the lower concentrations are already affected by incipient molybdenite precipitation. Phase separation concentrated Mo and most other elements in the brine, which contains 300-500 $\mu \mathrm{g} / \mathrm{g}$ Mo on average. The tendency for Mo partitioning into the saline liquid does not necessarily imply chloride complexation (which is unlikely in the light of limited experimental data; e.g. Candela and Holland 1984, but see preliminary data by Rempel et al. 2006) and more likely reflects the preference of molybdenum hydroxy species for the more hydrated environment of the denser liquid phase, comparable to the solution behaviour of $\mathrm{SiO}_{2}$ (Newton and Manning 2000).

The spatial association between molybdenite inclusions on growth zones in the quartz crystals and pseudosecondary brine trails in samples from the magmatic-hydrothermal breccia and from stockwork veins indicates that molybdenite precipitated mainly from the brine and only to a minor extent from the intermediate-density fluids or the vapour phase (see Fig. 3). The $\mathrm{Mo} /(\mathrm{Na}+\mathrm{K}+\mathrm{Mn}+\mathrm{Fe})$ ratios of the $\mathrm{B} 1_{\mathrm{MHBX}}$ brine inclusions decrease systematically over two orders of magnitude with decreasing total homogenisation temperature $\left(\mathrm{T}_{\mathrm{h}, \text { tot }}\right)$ from about $420^{\circ} \mathrm{C}$ to $360^{\circ} \mathrm{C}$, whereas 


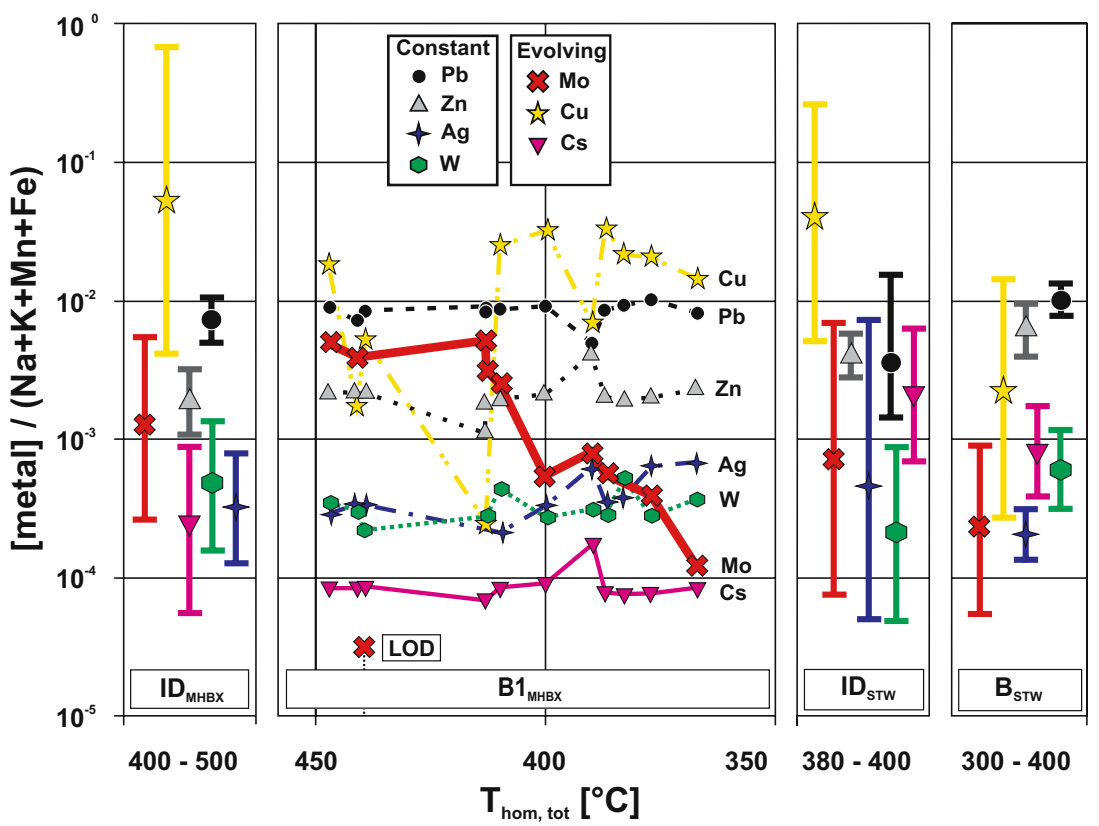

Fig. 8 The evolution of the ore metals relative to the sum of main elements of the fluids $(\mathrm{Na}+\mathrm{K}+\mathrm{Mn}+\mathrm{Fe})$ against homogenisation temperature of the fluid inclusions is shown for the magmatichydrothermal breccia (MHBX) and the later stockwork veins (STW). Elements not involved in fractionation or precipitation processes such as $\mathrm{Zn}, \mathrm{Ag}, \mathrm{W}$, and $\mathrm{Pb}$ show constant ratios over the entire evolution of

all other cation ratios remain constant over this temperature interval (Fig. 8). This demonstrates that a temperature decrease caused molybdenite precipitation from the brine, precipitating $99 \%$ of Mo over less than $100^{\circ} \mathrm{C}$ cooling, just after the onset of phase separation at about $420^{\circ} \mathrm{C}$. These data imply a minimum Mo solubility of about $700 \mu \mathrm{g} / \mathrm{g}$ at $420^{\circ} \mathrm{C}$ in a high-salinity, magmatichydrothermal liquid.

$\mathrm{The} \mathrm{Mo} / \mathrm{Cu}$ ratio in the intermediate-density fluids at Questa is about $0.010(=40 \mu \mathrm{g} / \mathrm{g} \mathrm{Mo} / 4,000 \mu \mathrm{g} / \mathrm{g} \mathrm{Cu})$. This is very similar to the single-phase fluids trapped prior to chalcopyrite saturation at the porphyry- $\mathrm{Cu}-\mathrm{Mo}$ deposit of Bingham Canyon (Mo/Cu $\sim 0.014$; Landtwing 2004). This leads to the conclusion that $\mathrm{Cu}$, although present in the input fluid in high concentration, was not deposited in the ore bodies at Questa. Phase separation and boiling off of a low-salinity vapour phase has probably led to selective copper removal and the formation and accumulation of residual brine near the roof of the granite intrusion. Ore deposition by a dense brine could explain the horizontally stratified shape of the ore bodies (Fig. 1c; Ross et al. 2002). Escaping vapour will take significant amounts of $\mathrm{Cu}$ and, probably S, (Heinrich et al. 1999) out of the system. Low concentrations of reduced sulphur already in the primary ore fluids and/or further depleted by vapour escape is suggested to be the reason why only molybdenite precipitated at Questa, but virtually no chalcopyrite and pyrite despite high initial $\mathrm{Cu}$ and $\mathrm{Fe}$ content of the fluids. the hydrothermal fluid from early intermediate-density (ID) to coexisting brine (B) and vapour inclusions. The Cs-ratios increase from the MHBX stage to the STW stage significantly. Molybdenum ratios of $\mathrm{B}_{\mathrm{MHBX}}$ inclusions decrease with decreasing temperature from $\sim 410$ to $360^{\circ} \mathrm{C}$ suggesting $99 \%$ precipitation of molybdenite

Fluid source, magma evolution and the origin of Mo-only porphyries

The preceding discussion on fluid evolution within the Questa deposit indicates that this porphyry Mo ore body differs from the more common porphyry-Cu-(-Mo-Au) deposits by non-precipitation of copper iron sulphides, probably due to selective $\mathrm{Cu}$ and $\mathrm{S}$ loss to an escaping vapour phase. In addition, characteristic differences in the composition of the single-phase input fluids, relating to the evolution of their magmatic source, further contribute to the contrasting metal ratios. The $\mathrm{Mo} / \mathrm{Cu}$ ratio in the intermediate-density fluids at Questa of about 0.010 is at least ten times higher than in similar fluids from the Continental ore body at Butte $(<10 \mu \mathrm{g} / \mathrm{g} \mathrm{Mo} / 10,000 \mu \mathrm{g} / \mathrm{g}$ $\mathrm{Cu}$; Rusk et al. 2004). Apart from the dominant copper resource at Butte, the fivefold difference in Mo ore grade at Questa $(0.14 \% \mathrm{Mo})$ compared with Butte $(0.028 \% \mathrm{Mo})$ approximately matches the corresponding difference in the Mo content of the otherwise quite similar low-salinity and weakly $\mathrm{CO}_{2}$-bearing input fluids. This indicates a process of differentiation of metal endowments that probably occurred prior to the exsolution of the ore fluids from their source magmas. Selective Mo enrichment at Questa can either be caused by fractional crystallisation of the source magma or by a primary Mo enrichment already present in the parental magma. Our fluid compositional results from Questa, in conjunction with published data from barren 
plutons in the Questa Caldera (Johnson et al. 1989, 1990; Audétat and Pettke 2003) indicate that both factors probably contributed to the specialised ore fluids that generated the Questa deposit.

Fluid and melt inclusion analyses from quartz phenocrysts and miarolitic cavities record the final stages of crystal fractionation and concurrent local fluid exsolution within the unmineralised Rito del Medio and Cañada Pinabete plutons. It occurred at a lithostatic fluid pressure of 1.2$1.3 \mathrm{kbar}$, consistent with petrologic constraints and the observed gradual increase in the salinity of the exsolving fluid (Audétat and Pettke 2003). Taking the highly incompatible element $\mathrm{Cs}$ as a monitor of progressive magma crystallization, the fluid inclusion compositions from Questa (where no co-existing silicate melt inclusions in hydrothermal quartz could be identified) can be compared to the evolution of Rito del Medio (where co-existing fluid and melt inclusions are recorded, providing empirical fluidmelt distribution coefficients). The single-phase fluids of the stockwork veining stage (inclusions ID $_{\mathrm{STW}}$ ) from Questa closely approximate stage 'Rito5lastGZ' fluids in the barren pluton, which records the transition from the last stage of fluid-saturated crystallisation of phenocrysts to the beginning of open-space crystallisation in miarolitic cavities (Audétat and Pettke 2003). Coexisting fluids ( 4.5 wt. $\%$ salinity) and melts contain 130 and $14 \mathrm{ppm}$ Mo, respectively, corresponding to a fluid-melt distribution coefficient of $\sim 9$. Using the same Mo distribution coefficient and the average Mo content of $36 \mathrm{ppm}$ analysed in the

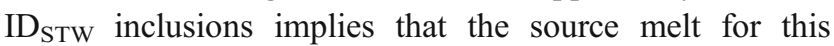
mineralisation stage at Questa contained about $4 \mathrm{ppm}$ Mo on average, or up to $10 \mathrm{ppm}$ if the highest analysed Mo concentrations in the fluids are taken as representative of the input ore fluids (above). Extracting $4 \mathrm{ppm}$ Mo from a crystallising silicate melt into the exsolving volatile phase requires a minimum of $60 \mathrm{Gt}$ or $25 \mathrm{~km}^{3}$ melt, in order to liberate $0.24 \mathrm{Mt}$ Mo presently contained in the stockwork veins $(\sim 60 \%$ of the total molybdenum reserves of the Questa deposit; Ross et al. 2002). This estimate demonstrates that fluid exsolution occurred from a large mass of silicate magma - much larger than the mass of rock forming the host Sulphur Gulch intrusion. Assuming complete precipitation of $0.24 \mathrm{Mt}$ metal introduced by a fluid initially containing $36 \mathrm{ppm}$, Mo requires 7 Gt fluid.

Comparison of this fluid quantity with the estimated mass of silicate melt implies an initial water content in the source melt of $\sim 10 \%$. Note that the values used for this simple calculation have large uncertainties in absolute concentrations and resulting amounts of source melt and ore fluid. However, the water/melt ratio is determined by the fieldderived fluid-melt distribution coefficient for Mo, which is well defined at $9 \pm 4$ by the data of Audétat and Pettke (2003). Lower $\mathrm{D}_{\mathrm{Mo}, \mathrm{F} / \mathrm{M}}$ values (as indicated by published experi- ments using compositionally simpler systems; Candela and Holland 1984; Keppler and Wyllie, 1991) would even further increase the required water content of the melt at the time of fluid exsolution. Ten percent water is not soluble in a normal granitic source melt unless the confining pressure is very high (5-6 kbar; Burnham 1979) or the granitic melt is enriched in fluxing agents such as $\mathrm{F}$ or $\mathrm{Cl}$. The $\mathrm{Cs}$ concentration of the MHBX forming fluid does not indicate an extremely fractionated source melt, however. Therefore, it can be hypothesised that the confining pressure in the granitic source magma was high during fluid exsolution, suggesting that it occurred well below the Sulphur Gulch stock intrusion immediately underlying the Questa deposit, possibly at mid-crustal depths.

Other indications suggest that magma fractionation and ore fluid exsolution may have occurred already in the middle or even lower crust, as Halter et al. (2005), Rohrlach and Loucks (2005) and Klemm et al. (2007) have argued for porphyry copper deposits. At Questa, a $\sim 20$-fold increase in Cs concentration is associated with a change from $\mathrm{CO}_{2}$ bearing intermediate-density fluids in the early MHBX to $\mathrm{CO}_{2}$-poor fluids in the later STW stage, without any systematic increase in salinity. The presence of $\mathrm{CO}_{2}$ in the MHBX inclusions is consistent with a higher load pressure in the Questa fluid source than at Rito del Medio, where Audétat and Pettke (2003) detected no $\mathrm{CO}_{2}$ in the fluids. These authors found that salinity increases with fractional crystallisation and fluid exsolution due to the preferential partitioning of $\mathrm{H}_{2} \mathrm{O}$ over chloride into the fluid at $P<1.5$ kbar (Cline and Bodnar 1994) but still with plagioclase as the major fractionating phase (Johnson et al. 1989). In addition, the concentrations of the most incompatible elements (Cs, Li) in the early fluids of the MHBX stage at Questa are lower than any fluids recorded at Rito del Medio, implying that less fractionated melts gave rise to the first mineralization pulse at Questa. Early fluid saturation in the deep cumulate zone of a vertically extensive magma chamber beneath the exposed plutons of the Questa caldera was previously proposed by Johnson et al. (1989) to explain the compositional variation of intimately associated metaluminous and peralkaline intrusions of otherwise similar trace-element parentage. Fluids fluxing the midcrustal cumulates may even have originated from a deep basaltic intrusion represented by coeval mafic dykes, which probably contributed to the deep heat input for the longlived ( $\sim 6 \mathrm{Ma}$; Johnson et al. 1989) igneous province.

It is not known what triggered the two apparently separated pulses of mineralisation at Questa. If the two fluid pulses are indeed related to the same parental magma, the 20-fold increase in Cs concentration requires approximately $95 \%$ crystallisation from the early (MHBX) to the later (STW) stage of ore fluid exsolution. The required total magma volume is, therefore, about 20 times larger than the 
$25 \mathrm{~km}^{3}$ estimated above as the minimum melt volume needed for the stockwork vein stage, i.e. on the order of 500 $\mathrm{km}^{3}$. This magma volume is similar to the eruption volume of the Amalia Tuff that led to caldera formation (Johnson et al. 1989) and consistent with geophysical evidence indicating a large batholith extending beyond the southern margin of the large Questa caldera ( $>400 \mathrm{~km}^{3}$; Cordell et al. 1985, Long et al. 1985). The magma source volume required to form the Questa deposit is very large compared to the size of upper-crustal magma chambers proposed by some authors as the fluid source for the formation of major porphyry-Cu-Au deposits (e.g. Dilles 1987; Cline and Bodnar 1994; Ulrich 2002; Halter et al. 2005).

Despite a 20-fold increase in the fluid $\mathrm{Cs}$ and $\mathrm{Li}$ contents, which is most likely explained by high degrees of fractional crystallisation in the magma source, there is no concomitant increase in the Mo content of the fluids. In other words, the early Cs-poor fluids of the MHBX stage are no less Mo-rich than those of the later STW stage. As there is little change in major element composition of the fluids (with the exception of decreasing $\mathrm{CO}_{2}$ ), it is unlikely that the fluid-melt partition coefficient changed dramatically, implying that the earliest ore fluid generating melt already had Mo content of $4-10 \mathrm{ppm}$. This is higher than the Mo content in average crustal rocks ( $\sim 1 \mathrm{ppm}$; Newsom 1995) or even in rhyolite melts associated with the Pine Grove porphyry Mo deposit ( $3 \pm 1 \mu \mathrm{g} / \mathrm{g}$; Lowenstern 1994). These observations probably indicate an inherent largescale Mo enrichment of the crust or lithospheric mantle that contributed to the world's premier molybdenum province in Colorado and New Mexico. Witnesses of such a specially Mo-rich domain are, besides the three largest known Climaxtype Mo porphyries in the world, older molybdenum deposits of Palaeozoic and Precambrian age (e.g. Tweto 1960, Fulp 1987).

\section{Conclusions}

We have determined the physical and chemical history of fluids in relation to the paragenetic evolution of the Questa porphyry molybdenum deposit and combined these new microanalyses with previously published geochemical fluid and melt inclusion data from volcanic rocks and barren intrusions in the Questa caldera. Based on these results, we can tentatively backtrack the large-scale magmatichydrothermal history that led to the formation of this deposit. The essential features of this qualitative process model may also apply to other, even larger Climax-type deposit in the world's premier porphyry molybdenum province.

The source of hydrothermal fluids apparently was a very large magmatic intrusion (on the order of $500 \mathrm{~km}^{3}$ or more) formed by melting of lower crust, probably by massive underplating of mafic mantle melts. This crustal melt was relatively Mo-rich from the onset $(4-10 \mu \mathrm{g} / \mathrm{g})$ compared to average continental crust $(\sim 1 \mu \mathrm{g} / \mathrm{g})$ and was, then, subject to severe crystal fractionation in the middle or lower crust to reach water saturation at $>10 \% \mathrm{H}_{2} \mathrm{O}$ in the melt. Two pulses of a single-phase, $\mathrm{CO}_{2}$-bearing aqueous fluid with an initial salinity of $\sim 7$ wt. $\% \mathrm{NaCl}_{\text {equiv. }}$, were released from the evolving magma at mid- to lower-crustal level. The two fluid pulses were separated by $\sim 95 \%$ fractional crystallisation of the initial melt, as indicated by a 20 -fold increase in the concentration of incompatible and fluid fractionating but otherwise non-reactive heavy alkalis (Cs, $\mathrm{Rb}$ ). The fluid pulses reached the site of the ore deposit located in the flat roof of an upper-crustal intrusion of porphyritic granite some $3-5 \mathrm{~km}$ below the paleosurface, producing two stages of molybdenite mineralisation: a magmatic-hydrothermal breccia subsequently cut by a stockwork of veins. Apart from the increased $\mathrm{Cs}$ and $\mathrm{Rb}$ concentrations, both fluid pulses had similar composition with initial $\mathrm{Cu} \gg \mathrm{Mo}$, and both underwent a similar evolution within the deposit. Fluid phase separation by decompression from near-lithostatic to near-hydrostatic conditions led to the boiling off of a large amount of $\mathrm{Cu}$-enriched vapour, thereby generating Moenriched $(\sim 500 \mathrm{ppm})$ but $\mathrm{Cu}$, and probably $\mathrm{S}$, depleted residual brine that ponded in the roof region of the granite porphyry. Molybdenite precipitation occurred by cooling of this brine from $420^{\circ} \mathrm{C}$ to $350^{\circ} \mathrm{C}$, as indicated by a $\sim 100$ fold decrease in Mo concentrations correlated with falling homogenisation temperature of brine inclusion assemblages trapped in quartz next to molybdenite. No $\mathrm{Cu}$ and $\mathrm{Fe}$ sulphides co-precipitated with molybdenite throughout the deposit, probably because of limited availability of sulphur (rather than of $\mathrm{Cu}$ or $\mathrm{Fe}$ ) due the extreme boiling of the brine.

In summary, it appears that Questa, and possibly other giant Mo-only porphyries in the same province of the southwestern USA like Climax and Henderson, owe their particular metal endowment to a combination of preexisting enrichment of Mo in the continental crust, extreme crystal fractionation of volatile-rich magmas in the deeper parts of the crust and further enrichment in a residual oreforming brine in the upper crust associated with selective removal of $\mathrm{Cu}$ (and probably $\mathrm{Au}$ and $\mathrm{S}$ ) into an escaping vapour phase.

Acknowledgements We gratefully thank Molycorp, especially Bruce Walker, for provided access to drill core and underground workings for sampling and for the permission to publish this study. Eidgenössische Technische Hochschule Zurich is thanked for funding of the PhD scholarship to the first author. Prof. Dr. Eric Seedorff is thanked for his help with a reconnaissance study that included the Henderson Mo deposit where, unfortunately, the preservation of fluid inclusions proved to be inadequate for a detailed microchemical study of this type. 


\section{References}

Audétat A, Günther D (1999) Mobility and $\mathrm{H}_{2} \mathrm{O}$ loss from fluid inclusions in natural quartz crystals. Contrib Mineral Petrol 137:1-14

Audétat A, Pettke T (2003) The magmatic-hydrothermal evolution of two barren granites: A melt and fluid inclusion study of the Rito del Medio and Canada Pinabete plutons in Northern New Mexico (USA). Geochim Cosmochim Acta 67:97-121

Bethke PM, Lipman PW (1989) Questa caldera and associated porphyry molybdenum mineralization, Latir Volcanic Field, Sangre de Christo Mountains, and Rio Grande Rift. In: Mineralization in silicic calderas: Geophysical Union, 28th International Geologic Congress, Washington DC, Field trip guidebook T320:1-15

Bloom MS (1981) Chemistry of inclusion fluids-stockwork molybdenum deposits from Questa, New Mexico, and Hudson Bay Mountain and Endako, British-Columbia. Economic Geology 76:1906-1920

Bodnar RJ, Vityk M (1994) Interpretation of microthermometric data for $\mathrm{H}_{2} \mathrm{O}-\mathrm{NaCl}$ fluid inclusions. In: De Vivo B, Frezzotti ML (eds) Inclusions in minerals, short course of working group (IMA). IMA, Pontignano

Burnham CW (1979) Magmas and hydrothermal fluids. In: Barnes JW (ed) Geochemistry of hydrothermal ore deposits. Wiley, New York, pp 71-136

Candela PA, Holland HD (1984) The partitioning of copper and molybdenum between silicate melts and aqueous fluids. Geochim Cosmochim Acta 48:373-380

Carten RB, Geraghty EP, Walker BM (1988) Cyclic development of igneous features and their relationship to high-temperature hydrothermal features in the Henderson porphyry molybdenum deposit, Colorado. Econ Geol 83:266-296

Carten RB, White WH, Stein HJ (1993) High-grade granite-related molybdenum systems: Classification and origin. In: Kirkham RV, Sinclair WD, Thorpe RI, Duke JM (eds) Mineral deposits modelling. Geological association of Canada, Special paper 40:521-554

Cline JS (1991) Salinity variation in magmatic-hydrothermal fluids in the Questa, New Mexico, U.S.A., Porphyry molybdenum deposit: A product of pressure fluctuation. PLINIUS - Supplemento italiano all'Europan Journal of Mineralogy 5:45-46

Cline JS, Bodnar RJ (1994) Direct evolution of brine from a crystallizing silicic melt at the Questa, New-Mexico, molybdenum deposit. Economic Geology 89:1780-1802

Cline JS, Vanko DA (1995) Magmatically generated saline brines related to molybdenum at Questa, New Mexico, USA. In: Thompson JFH (ed) Magmas, fluids, and ore deposits: Mineralogical Association of Canada short course series. Mineralogical Association of Canada, Victoria, pp 153-174

Cordell L, Long CL, Jones DW (1985) Geophysical expression of the batholith beneath Questa caldera, New-Mexico. J Geophys ResSolid Earth and Planets 90:1263-1269

Czamanske GK, Foland KA, Kubacher FA, Allen JC (1990) The ${ }^{40} \mathrm{Ar} /{ }^{39} \mathrm{Ar}$ chronology of caldera formation, intrusive activity and Mo-ore deposition near Questa, New Mexico. New Mexico Geological Society guidebook 41. New Mexico Geological Society, Socorro

Diamond LW (1992) Stability of $\mathrm{CO}_{2}$ clathrate hydrate $+\mathrm{CO}_{2}$ liquid $+\mathrm{CO}_{2}$ vapour+aqueous $\mathrm{KCl}-\mathrm{NaCl}$ solutions-experimentaldetermination and application to salinity estimates of fluid inclusions. Geochim Cosmochim Acta 56:273-280

Dilles JH (1987) Petrology of the yerington batholith, NevadaEvidence for evolution of porphyry copper ore fluids. Econ Geol 82:1750-1789

Driesner T, Heinrich CA (2007) The system $\mathrm{H}_{2} \mathrm{O}-\mathrm{NaCl}$. I. Correlation formulae for phase relations in temperature-pressure-composition space from 0 to $1,000^{\circ} \mathrm{C}, 0$ to $5000 \mathrm{bar}$, and 0 to $1 \mathrm{XNaCl}$. Geochimica et Cosmochimica Acta 71:4880-4901

Fulp MS (1987) Proterocoic tungsten mineralization in the southern Sangre de Cristo Mountains, New Mexico. Geological Society of America annual meeting 19. GSA, Boulder, p 7

Günther D, Audétat A, Frischknecht R, Heinrich CA (1998) Quantitative analysis of major, minor and trace elements in fluid inclusions using laser ablation inductively coupled plasma mass spectrometry. J Anal At Spectrom 13:263-270

Halter W, Heinrich C, Pettke T (2005) Magma evolution and the formation of porphyry-Cu-Au ore fluids: evidence from silicate and sulfide melt inclusions. Min Deposita 39:845-863

Heinrich CA, Günther D, Audétat A, Ulrich T, Frischknecht R (1999) Metal fractionation between magmatic brine and vapor, determined by microanalysis of fluid inclusions. Geology 27:755-758

Heinrich CA, Pettke T, Halter WE, Aigner-Torres M, Audétat A, Günther D, Hattendorf B, Bleiner D, Guillong M, Horn I (2003) Quantitative multi-element analysis of minerals, fluid and melt inclusions by laser ablation inductively-coupled-plasma massspectrometry. Geochim Cosmochim Acta 67:3473-3497

Ishihara S (1967) Molybdenum mineralization at Questa mine, New Mexico, U.S.A. Geological Survey of Japan report No. 218. Geological Survey of Japan, Japan, pp 1-64

Johnson CM, Lipman PW (1988) Origin of metaluminous and alkaline volcanic rocks of the Latir Volcanic Field, Northern Rio Grande Rift, New Mexico. Contrib Mineral Petrol 100:107-128

Johnson CM, Czamanske GK, Lipman PW (1989) Geochemistry of intrusive rocks associated with the Latir Volcanic Field, New Mexico, and contrasts between evolution of plutonic and volcanic rocks. Contrib Mineral Petrol 103:90-109

Johnson CM, Lipman PW, Czamanske GK (1990) H, O, Sr, Nd, and $\mathrm{Pb}$ isotope geochemistry of the Latir Volcanic Field and cogenetic intrusions, New-Mexico, and relations between evolution of a continental magmatic center and modifications of the lithosphere. Contrib Mineral Petrol 104:99-124

Jones DM (2002) Magma mixing and mineralization: empirical evidence from Questa (Mo), N.M., USA; Nukay (Au-Cu), Guerrero, Mexico; Las Bambas (Cu-Au), Peru. Geological Society of America Denver annual meeting. GSA, Denver

Keppler H, Wyllie PJ (1991) Partitioning of Cu, Sn, Mo, W, U, and Th between melt and aqueous fluid in the systems haplogranite$\mathrm{H}_{2} \mathrm{O}-\mathrm{HCl}$ and haplogranite- $\mathrm{H}_{2} \mathrm{O}-\mathrm{HF}$. Contrib Mineral Petrol 109:139-150

Kilinc IA, Burnham CW (1972) Partitioning of chloride between a silicate melt and co-existing aqueous phase from 2 to 8 kbars. Econ Geol 67:231-235

Klemm LM, Pettke T, Hienrich CA, Campos E (2007) Hydrothermal evolution of the El Teniente deposit, Chile: Porphyry Cu-Mo ore deposition from low-salinity magmatic fluids. Econ Geol 102:1021-1045

Landtwing M (2004) Fluid evolution and ore mineral precipitation at the Bingham porphyry-Cu-Au-Mo deposit, Utah, deduced from cathodoluminescence imaging and LA-ICPMS microanalysis of fluid inclusions, PhD Thesis No. 15361. ETH Zurich, Zurich, p 260

Laughlin AW, Rehrig WA, Mauger RL (1969) K-Ar chronology and sulfur and strontium isotope ratios at Questa mine, New Mexico. Econ Geol 64:903-909

Lipman PW, Reed JC Jr (1989) Geologic map of the Latir volcanic field and adjacent areas, Northern New Mexico. USGS, Socorro, pp 1-1907

Lipman PW, Mehnert HH, Naeser CW (1986) Evolution of the Latir Volcanic Field, Northern New-Mexico, and its relation to the Rio Grande rift, as indicated by potassium-argon and fission track dating. J Geophys Res_-Solid Earth and Planets 91:6329-6345 
Long CL (1985) Regional audiomagnetotelluric study of the Questa caldera, New Mexico. J Geophys Res - Solid Earth and Planets 90:1270-1274

Longerich HP, Jackson SE, Günther D (1996) Laser ablation inductively coupled plasma mass spectrometric transient signal data acquisition and analyte concentration calculation. J Anal At Spectrom 11:899-904

Lowenstern JB (1994) Dissolved volatile concentrations in an ore forming magma. Geology 22:893-896

Molling PA (1989) Applications of the reaction progress variable to hydrothermal alteration associated with the deposition of the Questa molybdenite deposit, NM. Ph.D. thesis. John Hopkins University, Baltimore, p 229

Newsom HE (1995) Composition of the solar system, planets, meteorites, and major terrestrial reservoirs. In: Ahrens TJ (ed) Global earth physics: a handbook of physical constants. AGU Reference Shelf, American Geophysical Union, Washington, DC, pp 159-189

Newton RC, Manning CE (2000) Quartz solubility in $\mathrm{H}_{2} \mathrm{O}-\mathrm{NaCl}$ and $\mathrm{H}_{2} \mathrm{O}-\mathrm{CO}_{2}$ solutions at deep crust-upper mantle pressures and temperatures: $2-15 \mathrm{kbar}$ and $500-900^{\circ} \mathrm{C}$. Geochim Cosmochim Acta 64:2993-3005

Pettke T, Halter WE, Webster JD, Aigner-Torres M, Heinrich CA (2004) Accurate quantification of melt inclusion chemistry by LA-ICPMS: a comparison with EMP and SIMS and advantages and possible limitations of these methods. Lithos 78:333-361

Rempel KU, Migdisov AA, Williams-Jones AE (2006) The solubility and speciation of molybdenum in water vapour at elevated temperatures and pressures: Implications for ore genesis. Geochim Cosmochim Acta 70:687-696

Roedder E (1984) Fluid inclusions. Rev Min 12:644

Rohrlach BD, Loucks RR (2005) Multi-million-year cyclic ramp-up of volatiles in a lower-crustal magma reservoir trapped below the Tampakan $\mathrm{Cu}-\mathrm{Au}$ deposit by Mio-Pliocene crustal compression in the Southern Philippines. In: Porter TM (ed) Super porphyry copper and gold deposit — a global perspective. PGC, Adelaide, pp 369-407
Ross PS, Jebrak MJ, Walker BM (2002) Discharge of hydrothermal fluids from a magma chamber and concomitant formation of a stratified breccia zone at the Questa porphyry molybdenum deposit, New Mexico. Econ Geol 97:1679-1699

Rowe A (2005) Fluid evolution of the magmatic-hydrothermal breccia of the Goat Hill orebody, Questa Climax-type porphyry molybdenum system, New Mexico - a fluid inclusion study, M.Sc. thesis. Department of Earth and Environmental Science. New Mexico Institute of Mining and Technology, Soccorro, p 134

Rowe A, Campbell AR, McLemore VT, Norman DI, Walker BM (2003) The Goat Hill orebody, Questa porphyry Mo system, New Mexico - a geochemical study of a stratified magmatichydrothermal breccia and stockwork veinlets. Geological Society of America Seattle Annual Meeting. GSA, Seattle, pp 93-13

Rusk BG, Reed MH, Dilles JH, Klemm LM, Heinrich CA (2004) Compositions of magmatic-hydrothermal fluids determined by LA-ICPMS of fluid inclusions from the porphyry coppermolybdenum deposit at Butte, MT. Chem Geol 210:173-199

Singer DA, Berger VI, Moring BC (2005) Porphyry copper deposits of the world: database, map, and grade and tonnage models. U.S. Geological Survey Open file report 2005-1060, (http://pubs.usgs. gov/of/2005/1060/)

Stein HJ, Hannah JL (1985) Movement and origin of ore fluids in Climax-type systems. Geology 13:469-474

Sterner SM, Bodnar RJ (1989) Synthetic fluid inclusions.7. Reequilibration of fluid inclusions in quartz during laboratorysimulated metamorphic burial and uplift. J Metamorph Geol 7:243-260

Tweto O (1960) Scheelite and powellite in the precambrian gneisses of Colorado. Econ Geol 55:1406-1428

Ulrich T (2002) The solubility of molybdenum determined in synthetic fluid inclusions by LA-ICPMS analysis. Geochim Cosmochim Acta 66:A503-A503

Wallace SR, Mackenzie WB, Blair RG, Muncaster NK (1978) Econ Geol 73:325-368 